\title{
One Hundred Years of Solicitude: Intellectual Property Law, 1900-2000
}

\author{
Robert P. Merges $\dagger$
}

TABLE OF CONTENTS

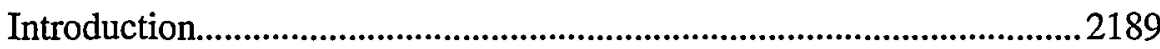

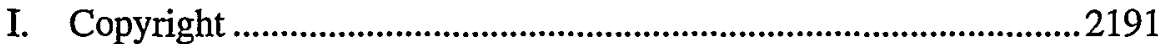

A. The 1909 Act: Progressive-Victorian Copyright ......................2192

B. The (Progressive) Spirit of 1976 .................................................2194

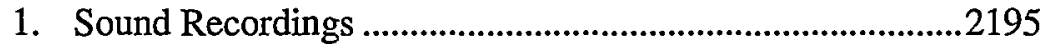

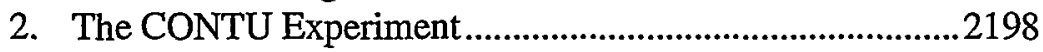

C. Rushing into the eFray: Digital Copyright Legislation .............2200

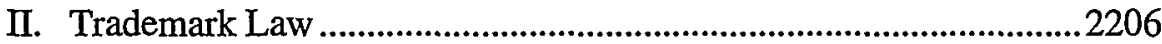

A. Mass Consumer Markets and Trademarks ..............................2206

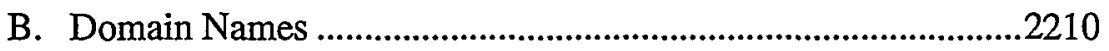

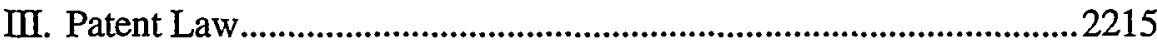

A. Corporatization of Industrial R\&D............................................2215

1. Employee Assignment Agreements......................................2217

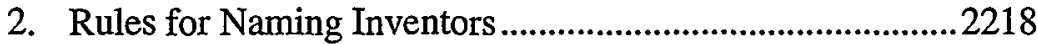

3. Accommodating Patent Portfolios .......................................2219

B. The 1952 Patent Act: A Study in Legislative Consolidation....2221

C. The Federal Circuit.............................................................2224

1. The Federal Circuit and Biotechnology Patents ..................22225

2. The Federal Circuit and Software Patents............................2228

D. Online Busmess Methods: Byting Off More than They Can

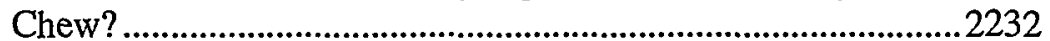

IV. The Road Ahead …......................................................................2233

A. The First Deadly Sin: "Pigging Out" at the IP Trough .............2233

Copyright @ 2000 California Law Review, Inc. California Law Review, Incorporated (CLR) is a California nonprofit corporation. CLR and the authors are solely responsible for the content of their publications.

$\dagger \quad$ Wilson Sonsini Goodrich \& Rosati Professor of Law and Technology, Co-director, Center for Law and Technology, School of Law, University of California, Berkeley (Boalt Hall). Thanks to Professor Mark Lemley for help with the Digital Millennium Copyright Act, and to Ines Gonzalez for research assistance. The usual disclaimer applies. 
1. Intellectual Property Legislation: Political-Economy Considerations

.2234

B. The Second Deadly Sin: The Shifting Baseline

.2239

Conclusion and Prospects 


\title{
One Hundred Years of Solicitude: Intellectual Property Law, 1900-2000
}

\author{
Robert P. Merges
}

The elaboration of intellectual property law is closely intertwined with new technologies. The Review Essay draws on selected episodes from the past 100 years to illustrate the three typical stages by which the legal system accomodates new technologies: (1) disequilibrium; (2) adaptation and adjustment; and (3) legislative consolidation. The final section of the Article introduces a cautionary contemporary note. As a byproduct of the increasing value of intellectual property, there has recently been a rapid increase in legislative activity, and concomitant lobbying activity. This changing political economy is greatly compressing the traditional threestep process, and may bypass it entirely in some circumstances. As a counterbalance to overzealous legislation, courts may be forced to look to the constitutional foundations of intellectual property as a source of limiting principles.

\section{INTRODUCTION}

Solicitude refers primarily to interest or concern, with a hint of anxiety or fearfulness; a feeling that something is not quite right. Those of us who study intellectual property law know these emotions all too well. Words like crisis, breakdown, overload pepper our work. ${ }^{1}$ Indeed, we scatter doom and disaster as liberally as punctuation in our writings, which took on a sort of millennial gloom well before the century's odometer started to roll over.

Methinks we doth protest too much-or at least not selectively enough. For in the past one hundred years, intellectual property law has often been said to be out-of-date, overwhelmed by the new technology of the day, and in need of a radical makeover. Each successive wave of new technology was, we were told, so different, so challenging, so fundamentally new, that this body of law had better adapt, and quick, or become

1. See, e.g., Benjamin Kaplan, AN UNHURRIEd VIEW OF COPYRIGHT 1 (1966) (“As a veteran listener at many lectures by copyright specialists over the past decade, I know it is almost obiigatory for a speaker to begin by invoking the 'communications revolution' of our time, then to pronounce upon the inadequacies of the present copyright act ....”). 
obsolete. First the large-scale industrial technologies of the turn of the century, then movies and radio, next computers and software, and lately, of course, the Internet: each new contrivance, we were told, had stretched and distorted the legal fabric so it no longer fit. Commentators of all kinds called for legal changes-now! - lest the body of law become outdated and out-of-touch. What was painted, in short, was a grim picture.

In this retrospective Essay, I argue that intellectual property law has generally adapted quite well to each successive wave of technological innovation. Typically, this adaptation has unfolded in three steps: (1) an early period of disequilibrium, when new technology may produce widely divergent results; (2) an extended period of adaptation, when general doctrines developed in earlier eras are applied and modified on a case-bycase basis; and (3) legislative consolidation, in which a major statutory overhaul codifies some of these doctrinal modifications. The overall effect of this three-stage process is the slow, steady extension of property rights over the products of new technologies.

This is not to say that all IP legislation states broad principles for courts to work out in specific cases as technology and economic conditions change. Discrete, problem-specific legislation is in fact quite common. Such responsive legislation has often been necessary when courts could not, or would not, stretch an extant statute to cover a new problem. Necessary, but not always effective.

Detailed, technology-specific provisions reflecting the passing concerns of a moment have proven difficult to adapt to new technologies. The IP system does best when it responds to new technologies with broad, enabling amendments. This leaves considerable room for maneuvering in the courts, and buys more time for the inevitable consolidation of quasicommon-law changes in major statutory revisions.

Detailed, technology-specific amendments thus thwart, to some extent, the quasi-common-law process by which IP law is elaborated. The recent erosion of what might be termed "legislative slack" is hardly surprising. Much more money is at stake in IP legislation than in the past. With higher stakes comes greater desire to nail down the details of protection-and greater reluctance to leave important issues to the courts. Economic theory and common sense both predict as much: more specific, highly elaborated property rights are worth lobbying for when the assets they cover are more valuable.

A solid economic logic therefore underlies the very active legislative scene in the contemporary IP world. There are some indications, however, that the logic is beginning to rnn amok. There is a fine line, after all, between a meritious property right and an odious government enforced 
rent. $^{2}$ In Part IV of this Essay I review concerns that some recent IP legislation reveals an excessively protectionist bias. Then in the concluding Part of this paper, I describe a limited response to some particularly insidious industry-specific legislation. The Supreme Court may have to step in at some point to regulate rent seeking in its boldest form. ${ }^{3}$ Though rare in recent years, there is a historical legacy of such intervention, beginning with the Trade-Mark Cases ${ }^{4}$ in the late nineteenth century. Thus what we need to do is rediscover this element of intellectual property regulation, to at least partially restore some balance.

This Essay begins by skimming over the century's highlights in each of the three major areas of intellectual property: copyright, trademark, and patent. At each turn, I relate these developments to the three-part process I identified above. Next, in Part IV, the Essay addresses the worrisome trend of legislation increasingly directed at industry- and even technologyspecific problems and issues. The conclusion discusses the courts' role in the trajectory of IP law-particularly the need for ongoing Supreme Court supervision of the quasi-common-law intellectual property system.

\section{COPYRIGHT}

Copyright over the past century has often been the focal point of significant anxieties over the law's ability to adapt to new technologies. Movies, radio and television, video recording, software: each new technology has produced cries of alarm over our "outdated" copyright system. ${ }^{5}$ Yet through a combination of judicial adaptation and legislative updates, the copyright system has - so far, at least - been up to the job at every turn.

This section discusses three of the most important developments in copyright law over the past century: the 1909 Act; the prologue to and promulgation of the 1976 Copyright Act (including the Commission on New Technological Uses of Copyright Works (CONTU)); and post-1976 doctrinal developments limiting the scope of software copyright under traditional concerns about functional works. In fits and starts, and with

2. Economists define rent as a supra-normal return, that is, a revenue higher than would be necessary to justify a given investment, taking into account a "normal" level of profit. See generally Alan W. Evans, On Monopoly Rent, 67 Land Econ. 1 (1991).

3. Rent-seeking is the expenditure of resources in an effort to capture these supra-normal returns; lobbying for special legislative privileges is a classic example. See Toward A THEORY OF THE Rent-SeEking Society (James M. Buchanan et al., 1980).

4. 100 U.S. 82 (1879).

5. See, e.g., Alisa E. Anderson, The Future of Software Copyright Protection: Arbitration v. Litigation, 12 Hastings Comm. \& ENT. L. J. 1, 4 (1989); Mary L. Mills, New Technology and the Limitiations of Copyright Law: An Argument for Finding Alternatives to Copyright Legislation in an Era of Rapid Technological Change, 65 CHI.-KENT L. REV. 307 (1989); Project, New Technology and the Law of Copyright: Reprography and Computers, 15 UCLA L. Rev. 939 (1968). 
numerous exceptions, the law has accommodated the advent of new technology with admirable flexibility. ${ }^{6}$

\section{A. The 1909 Act: Progressive-Victorian Copyright}

Two examples from the 1909 era, moving pictures and piano rolls, demonstrate how the law accommodated new technologies during this period. The advent of movies saw the courts in their best accommodation stance; through a harmless legal fiction, they permitted filmmakers to register and enforce copyrights, thus providing some protection for the fledgling industry. The piano roll story, however, is different: here Congress had to step in when the Supreme Court refused to interpret a piano roll-a physical, mechanical thing - as an embodiment of a musical composition. In both cases, copyright flexed to deal with new technologies and new industries.

Sometimes lost among his many inventions, the moving picture projector was one of Thomas Edison's personal favorites. ${ }^{7}$ Aesthetic interest aside, however, Edison was a notoriously aggressive businessman. So he set his sights, at the dawn of the cinema era, on nothing less than complete

6. See Paul Goldstein, Copyright's Highway: From Gutenberg to the Celestial JuKEBOX 33 (1994) ("In the two centuries since it passed the first American copyright act, [Congress] has been playing catch-up with new technologies...."); id. at 37 ("When Congress leaves its intentions unclear, some judges will read the Copyright Act expansively to cover a new technology; others stick strictly to the words of the old statute."). Professor Goldstein's "mixcd bag" position is similar to my description of "reasonable accommodation," while the views of Professor Jessica Litman are decidedly more negative, as she draws on numerous sources that argue that "current technology differs profoundly from prior development and calls into question the assumptions on which our copyright laws are based." See Jessica Litman, Copyright Legislation and Technological Change, 68 OR. L. REv. 275, 276 (1989) [hereinafter Litman, Technological Changel (citing Fleischmann, The Impact of Digital Technology on Copyright Law, 70 J. PAT. \& TRAdEMARK OfF. Soc'y 5 (1988); Office of Technology Assessment, U.S. Congress, Intellectual Property Rights in an Age OF ELECTRONICS AND INFORMATION (1986)). Litman does not believe copyright has kept up too well:

Throughout its history, copyright law has had difficulty accommodating tcchnological change. Although the substance of copyright legislation in this century has evolved from meetings among industry representatives whose avowed purpose was to draft legislation that provided for the future, the resulting statutes have done so poorly. The language of copyright statutes has been phrased in fact-specific language that has grown obsolete as new modes and mediums of copyrightable expression have developed. Whatever copyright statute has been on the books has been routinely, and justifiably, criticized as outmoded.

Litman, Technological Change, supra, at 276-77 (footnotes omitted). Despite the negative tone, Litman's scholarship contains many examples of relatively rapid response to technologieal change. As a result, the portion of her critique of copyright policy that centers on the rate of adaptation is not too convincing. Her expectations for quick, deeisive action seem excessive in light of institutional realities. Another part of her critique, though-that industry groups wield enormous influence in legislative drafting in this field-has considerable force. See id. at 275; Jessica D. Litman, Copyright, Compromise, and Legislative History, 72 CORNELl L. REv. 857 (1987) [hereinafter Litman, Copyright, Compromise, and Legislative Historyl. I discuss these issues in the last Part of this Essay, which deals with the political economy of intellectual property legislation.

7. See Neil Baldwin, Edison: Inventing the Century 272 (1995) (referring to Edison's "beloved kinetographic [moviel camera"). 
domination of the film industry-from filmmaking to distribution to exhibitions, he wanted it all. ${ }^{8}$

Early in this history, Edison's filmmaking company brought a copyright infringement suit against a rival, accusing the upstart competitor of making copies of popular Edison newsreel films. From the outset, the plaintiffs in Edison v. Lubin faced a challenge. The defendant sought to have the case dismissed on a technicality, but an important one at the time: improper registration of the copyrighted work. At the turn of the twentieth century, the Copyright Office had no provision for accepting registration and deposit of a full-length film. So new companies in the industry took to filing a series of individual still photos instead. The Third Circuit was asked in an appeal whether this practice satisfied the registration requirements of the Copyright Act. Its answer is the very embodiment of the accommodationist impulse in copyright law:

The mere circumstance that such positive is pictured on a strip of celluloid, and not on a strip of paper, is immaterial. In either event, the reproduction is a light-written, and therefore a photographic picture or photograph. To say that the continuous method by which this negative was secured was unknown when the act was passed, and therefore a photograph of it was not covered by the act, is to beg the question. Such construction is at variance with the object of the act, which was passed to further the constitutional grant of power 'to promote the progress of science and useful arts.' When Congress, in recognition of the photographic art, saw fit in 1865 to aniend the act of 1831 (13 Stat. 540), and extend copyright protection to a photograph or negative, it is not to be presumed it thought such art could not progress, and that no protection was to be afforded such progress. It must have recognized there would be change and advance in making photographs, just as there has been in making books, printing chromos, and other subjects of copyright protection. While such advance has resulted in a different type of photograph, yet it is none the less a photograph-a picture produced by photographic process. ${ }^{10}$

Despite this progressive tone, not all pre-1909 Act decisions favored the new media technologies of the day. Demonstrating an important countertrend that would find its way into a number of important decisions through the century, the Supreme Court in White-Smith Music Publishing Co. v. Apollo Co., ${ }^{11}$ held that a mechanical piano roll could not constitute a "copy" of a copyrighted musical composition:

8. See id. at 241-42 (discussing early version of motion picture projector, kinetograph, licensed to franchise exhibitors for showing of short films produced in Edison production "factory").

9. 122 F. 240 ( $3 \mathrm{~d}$ Cir. 1903).

10. Id. at 242 .

11. 209 U.S. 1 (1908). 
It may be true that in a broad sense a mechanical instrument which reproduces a tune copies it; but this is a strained and artificial meaning. When the combination of musical sounds is reproduced to the ear it is the original tune as conceived by the author which is heard. These musical tones are not a copy which appeals to the eye. In no sense can musical sounds which reach us through the sense of hearing be said to be copies, as that term is generally understood, and as we believe it was intended to be understood in the statutes under consideration. A musical composition is an intellectual creation which first exists in the mind of the composer; he may play it for the first time upon an instrument. It is not susceptible of being copied until it has been put in a form which others can see and read. The statute has not provided for the protection of the intellectual conception apart from the thing produced, however meritorious such conception may be, but has provided for the making and filing of a tangible thing, against the publication and duplication of which it is the purpose of the statute to protect the composer. $^{12}$

Almost before the ink was dry on the Apollo decision, however, Congress passed the 1909 Copyright Act, ${ }^{13}$ rejecting the Court's crabbed definition of a copy. ${ }^{14}$ This established another of the century's traditions: Congress's rather rapid tendency to correct the courts' occasional anti-progressive mistakes. ${ }^{15}$

Movies and piano rolls were only two of the new technologies developed early this century. The reception of these two into copyright may not be fully representative. But these two examples do illustrate two important points: that copyright early on showed an adaptability to new technologies that would serve it well all century long; and that the burden of adaptation was spread erratically, but roughly evenly, between Congress and the courts.

\section{B. The (Progressive) Spirit of 1976}

The long, tortuous history of the 1976 Copyright Act has often been told. ${ }^{16}$ I do not aim to repeat the saga here. I will instead focus on two aspects of the 1976 Act: the emergence of a separate copyright in sound recordings, as opposed to the musical compositions underlying them; and the

12. Id. at 17 .

13. Act of Mar. 4, 1909, Pub. L. No. 60-349, ch. 320, 35 Stat. 1075 (current version at 17 U.S.C. $\S \S 101-803)$.

14. See id. at $\$ 1(a)-(e)$ (listing exclusive rights of copyright owners).

15. I argue elsewhere that Congress perpetrated its own mistake in the 1909 Act by legislating a compulsory license for mechanical copies that changed very little over the years. See Robert P. Merges, Contracting into Liability, Rules: Intellectual Property Rights and Collective Rights Organizations, 84 CAL1F. L. REv. 1293, 1296 (1996) (citing mechanical compulsory license as example of "legislative lock-in" effect of compulsory licenses).

16. See, e.g., Litman, Copyright, Compromise, and Legislative History, supra note 6. 
CONTU, an interesting and largely successful experiment in comprehensive policymaking at the dawn of a new technological era.

\section{Sound Recordings}

Written music has been protected by copyright in the United States since $1831 .{ }^{17}$ As a result of the 1909 Act, by the early twentieth century the protection extended to mechanical copies of musical compositions as well. ${ }^{18}$ Yet despite this robust protection for music composers, for many years there was no explicit copyright protection for musicians whose performance of a composition was recorded and sold. Indeed, only with passage of the 1976 Copyright Act did Congress recognize separate copyrights in "sound recordings," first time.

This may seem strange given the lucrative inarket for sound recordings that began in the 1940s and accelerated in the 1950s. But there is an explanation, one that has important lessons to teach about the forces that push copyright forward. Prior to the 1960 s, record companies did not push especially hard for a separate copyright in sound recording because it was so difficult to make "pirated" copies of recordings in the vinyl record format. A good deal of artistry was required to render a recording session in an appealing way on vinyl..$^{20}$ It was much easier to produce reasonable quality sound by recording a live performance than by re-recording another record. ${ }^{21}$ It therefore made little sense for record companies to spend time and money lobbying for separate copyright protection of sound recordings. As for would-be entrants into the industry, it was much cheaper and easier to gain a foothold by introducing original recordings by new talent rather than to try to copy existing recordings. Indeed, the superiority of this business strategy left its mark on American popular culture, as independent record labels sprang up to challenge the large, integrated companies (the so-called Big Four). ${ }^{22}$ In this way, the independents introduced jazz, blues, country, folk, $R \& B$, and rock music into the inarket. ${ }^{23}$

The situation changed with-what else?-a new technology. Actually, a series of new technologies that together created a "revolution in sound." ${ }^{24}$ Beginning with electrical recording techniques (which replaced

17. See Act of Feb. 3, 1831, ch. 16, 4 Stat. 436 (codified at 17 U.S.C.).

18. See id. at $\$ 1$ (codified at 17 U.S.C. $\$ 1(\mathrm{e})$ ).

19. See 17 U.S.C. \$ 102(a)(7) (1994).

20. See ANdre Millard, America on Record: A History of Recorded Sound 261 (1995), ("Making a recording required an unusual mix of scientific precision and craft skills ....").

21. Cf. id at 245-48 (describing ubiquitous "field recordings" of folk and blues music by early ethnomusicologists).

22. See id. at 229. The Big Four were Columbia, RCA Victor, Decca, and Capitol. See id.

23. See id. at 226-27.

24. See id. at 201. 
the older acoustic recording system), ${ }^{25}$ continuing with the development of the long-play (LP) record forinat, ${ }^{26}$ and finally culminating in the development of magnetic tape recording for record "masters,"27 studio techniques underwent rapid changes during the 1940s.

This new technology changed the landscape of the record business in a number of interrelated ways. Most importantly, it increased the desirability of copying sound recordings. Predictably, with the advent of better sound quality, there arose a record piracy industry. Piracy-which was more a moral than legal label at this time, given the lack of direct protection for sound recordings-was a sinall matter at first. In the 1940 s, it was based on demand froin rabid jazz fans for obscure and discontinued records. ${ }^{28}$ Even at this early stage, commentators began to call for some sort of direct protection for sound recording. Law review coinments in particular pointed out that piracy was possible because sound recordings represented a gap in copyright's coverage. ${ }^{29}$

It is telling that at this early stage the record companies did not push aggressively for amendment of the copyright law. There was too little at stake. But this changed with the introduction and rapid diffusion of magnetic tape recording and cassette players in the $1960 \mathrm{~s}^{30} \mathrm{~A}$ quick survey of the reported piracy cases froin the emerging tape cassette era demonstrates two things: first, the pirates in all the reported cases from the late $1960 \mathrm{~s}$ onwards used cassette tape technology, demonstrating the rapid rise of this new medium; ${ }^{31}$ and second, intellectual property law broadly speaking reacted rather quickly. Even before the 1976 Copyright Act, record companies had successfully shut down pirate operations under a number of

25. See id. at 139-57 (describing emergence of electrical recording, which replaced the older technology of making direct imprints on "master" records made of soft material such as wax; and describing research, based on technologies from the telephone and "talking picture" industries).

26. See id. at 205. LP records in particular played a role in increasing the occurrence of sound recording piracy. See Comment, Piracy on Records, 5 STAN. L. REv. 433 (1953) ("[T]he introduction of long-playing records was a factor in the rapid expansion of piracy. The first 'dubs' had been ten-inch $78 \mathrm{rpm}$ singles, but 'LP's' made possible cheaper production of the more expensive and hence more profitable 'packages."').

27. See MrLlARD, supra note 20, at 200.

28. See Piracy on Records, supra note 26, at 433-35.

29. See id. at 440-41; Note, Rights of Performers and Recorders Against Unlicensed Record Broadcasts, 49 YALE L.J. 559 (1940).

30. See Register's Report on the General Revision of the U.S. Copyright Law, Written by Emanuel Celler, July 10, 1961, reprinted in 5 Melville Nimmer AND DAvid Nimmer, Nimmer on Copyright (1998), Appendix 14, at 18 (describing "bill aimed at the counterfeiting of records," introduced in 1961, and calling for criminal penalties in the case of counterfeit records, that is, illegal copies duplicating sound recordings, as well as logos and packaging of legitimate recording label).

31. See, e.g., Goldstein v. California, 412 U.S. 546, 549 (1973) ("At petitioners" plant, the recording was reproduced on blank tapes, which could in turn be used to replay the music on a tape player."); Liberty/UA, Inc. v. Eastern Tape Corp., 180 S.E.2d 414 (N.C. App. 1971) (tape piracy); Duchess Music Corp. v. Stern, 458 F.2d 1305 (9th Cir. 1972) (same). 
different theories, including state law misappropriation doctrines ${ }^{32}$ and special state legislation. ${ }^{33}$

The cassette tape recorder/player was the driving force behind these changes. Originally introduced as a "high-end" recording medium (one that revolutionized studio recording, in fact), the cassette tape player gained rapid popularity with consumers in the 1960s: sales exploded from 9,000 units in 1963 to 2.4 million units in $1968 .{ }^{34}$ It was suddenly cheap and easy to make copies of recorded music, and many pirate firms sprang up to do just that. According to the legislative history of the Sound Recording Amendment of 1971 , total "pirate" revenues at the time were $\$ 100$ million, coinpared with $\$ 300$ million for legitimate tape sales. ${ }^{35}$

This fundamental change in the economics of recorded music led to a swift, full-out campaign to protect sound recordings. And the campaign bore fruit quickly: a series of court decision $\mathrm{s}^{36}$ protected sound recordings by the early 1970s, and Congress added sound recording protection in 1973, which was carried forward into the 1976 Copyright Act. ${ }^{37}$

32. See, e.g., Capitol Records, Inc. v. Spies, 264 N.E.2d 874 (Ill. App. Ct. 1970). In Spies, the lower court had denied a temporary injunction, holding that prevention of record piracy under state law was precluded by federal preeinption doctrines. In reversing, the appellate court pointed out that:

Whereas in [federal preemption cases] the court was concerned with the copying of products which were not patented, in the instant case Spies was actually appropriating another's property. Rather than [these] decisions, we find that the case of [Int'l News Serv. v. Associated Press (a misappropriation case)] is controlling.

Id. at 876. For another decision rejecting a preemption argument and upholding an injunction based on a misappropriation theory, see Capitol Records, Inc. v. Erickson, 82 Cal.Rptr. 798, 806 (Cal. Ct. App. 1969). The appellate court in Erickson articulated its reasoning thus:

[Defendant] has not merely copied or imitated discs or tapes produced by Capitol, rather, [defendant] has appropriated the product itself-performances embodied on the records.... It is reasonable to conclude that permitting such appropriation would discourage invention and free competition-and that those engaged in the recording industry, would be inclined not to utilize their skill and efforts, and expend large amounts of money, in producing unique recordings, but would wait for a recording to be produced, and then duplicate it and sell it, at maximum profit and with minimum effort and expense.

Id. at 806. See also Columbia Broadcasting System, Inc. v. Custom Recording Co., 189 S.E.2d 305 (1972) (adopting misappropriation theory).

33. See, e.g., Goldstein, 412 U.S. at 571 (upholding California anti-piracy statute over federal preemption challenge).

34. See MiLlaRD, supra note 20 , at 317.

35. See H.R. ReP. No. 92-487 (1971), reprinted in 5 MEL VILle NimMER AND David Nimmer, NiMMER ON COPYRIGHT (1998), Appendix 18, at 18-3 (statement of Rep. Kastenmeier).

36. See cases cited supra note 32 .

37. See Act of Oct. 15, 1971 (McClellan anti-piracy amendment), Pub. L. No. 92-140, 85 Stat. 391 ("temporarily" amending the Copyright Act to recognize sound recordings as copyrightable subject matter). This Act applied only to recordings fixed on and after February 15, 1972. Congress later made this protection permanent, see Act of Dec. 31, 1974, Pub. L. No. 93-573, 88 Stat. 1873, and the comprehensive revision of 1976 continued that recognition and protection. See 17 U.S.C. $\$ 102(a)(7)$ (1994). Under the present Act, copyright protection attaches to original works of authorship fixed in any tangible medium of expression. See id. $\$ 102$. Sound recordings is defined as "works that result from the fixation of a series of musical, spoken, or other sounds, but not including the sounds accompanying a motion picture or other audiovisual work, regardless of the nature of the material objects, such as disks, tapes, or other phonorecords, in which they are embodied." Id. $\S 101$. A work is 
Of special interest in a sweeping review of copyright's development is the relationship between the market impact of pirated recordings and interest group pressure for legislative reform. The reduction in the cost of copying began to affect the recording market in a substantial way by the mid-1960s. This is evidenced by the commencement of "anti-pirate" litigation in the period from 1964 to 1973 . The state laws passed to remedy pirating survived a constitutional preemption challenge in $1973 .{ }^{38}$ And, by the early 1970 s, aggressive litigation based on various state law claims, along with impending federal legislation in the form of what became the 1976 Act, had succeeded in stripping pirates of whatever legal protection they had previously enjoyed.

Once again, the theme is the law's adaptation to a new technology. Cheap copying technology was the product of a series of incremental technical changes. However, it produced the same results as the concentrated, discrete "big bang" of videotaping or digital music transmission: a series of doctrinal adjustments (though admittedly largely under state law), capped off by a major consolidation of the new protections at the federal level (in the form of the $1976 \mathrm{Act}$ ). ${ }^{39}$

\section{The CONTU Experiment}

The National Commission on New Technological Uses of Copyrighted Works was created by Congress in a spasm of self-imposed rationality not often seen in intellectual property policymaking. The statute creating the Commission called for a cross-section of experts to meet, consult, and recommend policies. ${ }^{40}$ Their main task was to determine how to handle software under copyright law. ${ }^{41}$ Despite the criticism it has received over the years, ${ }^{42}$ CONTU did a creditable job. Although the precise dynamics of the CONTU process were unique, this episode in copyright history shows, once again, the system is quite able to adapt to new

\footnotetext{
"fixed" in a tangible medium of expression "when its embodiment in a copy or phonorecord, by or under the authority of the author, is sufficiently permanent or stable to permit it to be perceived, reproduced, or otherwise communicated for a period of more than transitory duration." Id. See also id. $\$ \$ 106,114$ (scope of sound recording copyright).

38. See Goldstein, 412 U.S. at 571.

39. The instinct of the courts to protect sound recordings found expression in state law misappropriation doctrine, among other theories. This illustrates a theme that several scholars have explored: the eapacity for courts to proteet intellectual property under general principles of restitution. See, e.g., Wendy J. Gordon, On Owning Information: Intellectual Property and the Restitutionary Impulse, 78 VA. L. REv. 149 (1992); Leo J. Raskind, The Misappropriation Doctrine as a Competitive Norm of Intellectual Property Law, 75 MiNN. L. REv. 875 (1991).

40. See Pub. L. No. 93-573, 93rd Cong., 1st sess., Dec. 31, 1974, reprinted in 5 NIMMER ON COPYRIGHT, Appendix 19 (1999).

41. See id. at $\$ 201(\mathrm{~b})$.

42. See generally Arthur R. Miller, Copyright Protection for Computer Programs, Databases, and Computer-Generated Works: Is Anything New Since CONTU?, 106 HARv. L. REv. 977, 985 n.26 (1993) ("Much of the existing secondary literature is critieal of CONTU ....").
} 
technologies. Indeed, with respect to the specifics of CONTU's organization, it might well serve as a paradigm for intellectual property policymaking.

The unique features of CONTU's background have been well documented. ${ }^{43}$ The long, arduous path to copyright reform seemed almost over when the issue of copyright for software burst on the scene in the late 1960 s and early 1970s. Software by nature posed very difficult problems for copyright law: here was a written text, classic copyrightable expression, that directly and immediately performed utilitarian work. Classic antinomies of copyright law were called into question: aesthetic versus utilitarian, expressive versus functional, and so on. ${ }^{44}$ The profound challenge to copyright theory was apparent to all at the time, and history has proved them right. Conflicts over these and other issues continue to the present day. ${ }^{45}$

In the short term, there was only one thing to do. Employing a classic of legislative strategy, a study commission was formed. This effectively bracketed the difficult issue of copyright for software, so that the carefully crafted progress of copyright reform would not be stalled. ${ }^{46}$ The Copyright Act of 1976 passed while CONTU was still meeting and discussing.

The other shoe dropped in 1979 when CONTU issued its final report. ${ }^{47}$ Despite what some have argued, ${ }^{48}$ the CONTU Report is a model docuinent, for two reasons. First, it is thoughtful. It shows a degree of selfawareness and sophistication not often encountered in the annals of legislative reform. At the practical level, the CONTU Report called for a modest set of statutory changes (for example, the right to make a backup copy of copyrighted software), ${ }^{49}$ all of which fit neatly into the policy cycle

43. See id.; Pamela Samuelson, CONTU Revisited: The Case Against Copyright Protection for Computer Programs in Machine-Readable Form, 1984 DuKE L.J. 633 (1984).

44. Copyright law excludes functional works from its protection. See 17 U.S.C. § 102(b) (denying copyright to "any idea, procedure, process, system, method of operation, concept, principle, or discovery, regardless of the form in which it is described, explained, illustrated, or embodied in such work").

45. See Mark A. Lemley et al., SofTware AND InTERnet LAw (2000) (Chapter 2: Copyright) (setting forth cases and commentary); Peter Menell, An Epitaph for Traditional Copyright Protection of Network Features of Computer Software, The AntrTrust Bulletin, Fall/Winter (1998); cf. Pamela Samuelson et al., Brief Amicus Curiae of Copyrigbt Law Professors in Lotus Development Corp. $v$. Borland Int'l, Inc., 3 J. INTEll. Prop. L. 103 (1995) (describing problems in the caselaw).

46. See Samuelson, supra note 43 , at 694.

47. National Commission on New Technological Uses of Copyrighted Works, Final REPORT (1979) [hereinafter CONTU REPORT].

48. See, e.g., Litman, Technological Change, supra note 6, at $347 \mathrm{n} .399$ (citations omitted): The [post-CONTU Report] amendments are widely, if not universally, acknowledged to have been disastrous. They have failed to meet the legitimate needs of either software proprietors or software users. Their most obvious flaw appears to be that the Commission had only superficial understanding of computers and less understanding about processes of software design and use.

49. See 17 U.S.C. $§ 117$ (1994 \& Supp. 1999). 
described in this article. ${ }^{50}$ The statutory changes are classic examples of what I earlier called legislative consolidation. They restated the consensus rules emerging from the case law, dampened the variance in judicial opinions, and generally sent a signal of stable progress.

The second remarkable aspect of the CONTU report is its detailed dissent, written by the noted nonfiction author John Hersey. ${ }^{51}$ One can imagine no finer lament for the wrenching changes about to convulse the copyright world than Hersey's measured, carefully phrased essay. In a now-famous analogy, he compared software code to the written equivalent of a rod containing a series of cams: the rotation of the rod "instructs" the cams to move mechanical parts in the same way that software tells the computer what to do next. ${ }^{52}$ For Hersey, the essence of software was that it was part of the machine, just like a rod and cam. The fact that code is written is a misleading artifact of this new type of engineering, and should not blind us to the fact that it is different-in kind as well as degree-from the texts that copyright law was formulated to protect.

The legal system rejected this well-considered advice, ${ }^{53}$ wisely, in my view. But it is difficult to argue with the process that produced the advice. The same basic procedure might make sense as a standard policymaking mechanism. Unfortunately for the quality of legislation in the copyright realm, the trend has been in the opposite direction. Copyright legislation is now seen as inevitably the simple product of interest-group negotiation..$^{54}$ Statutes codify industry deals, plain and simple. ${ }^{55}$ This is an unusual instance of pure academic theory in practice, ${ }^{56}$ but is not always conducive to good copyright policy - a theme I explore in detail in Part IV. A CONTUlike procedure would have been very helpful as background to recent legislation on digital copyrights, for example. The next Part tells why.

\section{Rushing into the eFray: Digital Copyright Legislation}

In the preceding paragraphs, I sketched a rather rosy picture of copyright's adaptability in the face of new technologies. Yet I did not say a

50. See CONTU REPORT, supra note 47, at 12; Pub. L. No. 96-517, 94 Stat. 3015, 3028 (1980) (codified at 17 U.S.C. $\S \S 101,117$ ) (amending the copyright statute to make explicit provision for computer software).

51. See CONTU REPORT, supra note 47 , at 27-37.

52. See id. at 29.

53. See, e.g., Apple Computer, Inc. v. Franklin Computer Corp., 714 F.2d 1240 (3d. Cir. 1983) (extending copyright protection to software code).

54. See infra Part IV.A.1.

55. See, e.g., Urged on by Disney, Congress Extends Copyrights by 20 Years, THE Legal INTELLIGENCER, Oct. 19, 1998.

56. On the notion that legislation is at heart all about the codification of interest-group "deals," see Frank H. Easterbrook, Statutes' Domains, 50 U. CHI. L. REv. 533 (1983). For a recent critique, see Mark L. Movsesian, Are Statutes Really "Legislative Bargains"? The Failure of the Contract Analogy in Statutory Interpretation, 76 N.C. L. REv. 1145 (1998). 
word about one of the great technological discontinuities of the age, the Internet. Does this novel technology pose a new challenge to copyright? Has the flexible adaptation I have described so far finally met its match?

The final answer is not yet in, but we do have some early results, in particular the 1998 Digital Millennium Copyright Act (DMCA). ${ }^{57}$ For many copyright mavens, the portents are not good. Pillars of the copyright community, from Pamela Samuelson ${ }^{58}$ to David Nimmer, ${ }^{59}$ together with many from the new generation of copyright scholars (such as Neil Netanel $^{60}$ and Yochai Benkler ${ }^{61}$ ) argue that the rushed, industry-backed DMCA is very deeply flawed. In the eyes of these observers, seldom has Congress responded to a new technology as swiftly and comprehensively as with the DMCA, and seldom has its handiwork been more frightening. In the terms I use in this review Essay, these copyright commentators argue that the DMCA falls well outside the traditional adaptation model that held throughout the twentieth century.

The DMCA enacted sweeping changes in copyright law, in direct response to what were seen as pressing challenges from the Internet. The crucial difference between the DMCA and earlier copyright legislation boils down to elapsed time: it was enacted in 1998, less than ten years into the "Internet era." The advent of ubiquitous digital networks capable of delivering copyrighted content was perceived by important industriesamong them, software, films, and music - as a defining moment for their future interests. ${ }^{62}$ They gathered together to lobby Congress. ${ }^{63}$ What they sought was legislation that makes the world safe for technological protection schemes capable of delivering copyrighted content over the Internet. An example is digital encryption technology, which makes content such as text, pictures, music, and movies unreadable except by those given access to the appropriate digital key. ${ }^{64}$ Given the potential econormic stakes and Congress's desire to please the new media industries, the end result surprised no one: strong legal recognition of technical protection schemes.

57. Digital Millenium Copyright Act, Pub. L. No. 105-304, 112 Stat. 2860 (1998) (codified in scattered sections of 17 U.S.C.).

58. Pamela Samuelson, Intellectual Property and the Digital Economy: Why the AntiCircunvention Regulations Need to Be Revised, 14 BERKELEY TECH. L. J. 519 (1999).

59. Melville Nimmier and David Nimmer, Nimmer on Copyright § 12 A.03 (1999).

60. Neil Netanel, Recent Developments in Copyright Law, 7 TEx. INTELL. Prop. J. 331, 332-33 (1999).

61. Yochai Benkler, Free As the Air To Common Use: First Amendment Constraints on the Enclosure of the Public Domain, 74 N.Y.U. L. Rev. 354 (1999).

62. The activities of the various industries are well documented in id. For a useful timeline describing the legislative evolution of the DMCA, see the Web site of the Digital Future Coalition, an influential public interest group, at $\langle\mathrm{http}$ //www.dfc.org $>$.

63. See Benkler, supra note 61, at 422 n.264.

64. See, e.g., Mark Stefik, Shifting the Possible; How Digital Property Rights Challenge Us to Rethink Publishing, 12 BERKELEY TECH. L.J. 137 (1997). 
The idea of strengthening property rights in content by regulating digital technologies is remarkable in itself, though it did have some antecedents in prior law. ${ }^{65}$ But what really has the commentators in a lather is the sheer scope of the DMCA's legislative innovations. The DMCA entailed two fundamental changes to our law of copyright. First, it directly prohibited the use of specific technologies: those that can be used to circumvent technological protection measures. ${ }^{66}$ The protection of expression, in other words, is for the first time achieved through the regulation of devices. And second, this regulation was added on top of a new list of infringing activities centering on the circumvention of technical protection schemes. Indeed, the two sets of provisions-those regulating the deployment of devices, and those defining illicit acts of circumvention-are so distinct that the detailed exceptions to the latter provisions do not apply at all to the former ${ }^{67}$ In practice this means that although Congress exempted certain uses of digitally protected works from the coverage of the "anticircumvention" section, it explicitly declined to exempt trafficking in devices whose sole purpose is to permit exempted uses. Thus David Nimmer concludes:

The upshot is that a library can obtain unauthorized access to a copyrighted work [under one specific exemption], but cannot manufacture or distribute devices or systems that either facilitate that access, or that take works to which access has been granted and defeat use restrictions put in place by the copyright owner. ${ }^{68}$

In other words, at least some commentators believe that the "use privileges" are personal to each user; they seemingly cannot be extended to others by sharing the device or technique through which the copy protection technology was circumvented. If accurate, this is but one example of the stringency of the Act. ${ }^{69}$ Commentators have begun to compile a long

65. Most notably, the Audio Home Recording Act of 1992 mandates that copy management technology be installed on each digital audio tape player sold in the United States. See 17 U.S.C. $\$$ 1002 (Supp. 1999); cf. Record Indust. Ass'n of Am. v. Diamond Multimedia Sys., lnc., 180 F.3d 1072 (9th Cir. 1999) (holding that portable device attachable to a computer hard drive, the "Rio" recorder/player that stores music in the digital MP3 format, did not fall under the provisions of the Act).

66. See id. 17 U.S.C. $\$ 1201$ (b)(1) (1994 \& Supp. 1999).

67. See id. § 1201(a); see generally Samuelson, supra note 58.

68. Melville Nimmer and David Nimmer, Nimmer on COPYRighr § 12A.03 (1999).

69. An intriguing counterargument is suggested by my colleague Pam Samuelson in her recent article, Intellectual Property and the Digital Economy: Why the Anti-Circumvention Regulations Need to Be Revised, supra note 58, at 549. Professor Samuelson argues that a "special purpose tool" designed to effectuate fair use may not fall under the definition of a "device ... primarily designed to circumvent protection afforded by a ... measure that effectively protects a right of the copyright owner...." (citing 17 U.S.C. $\$ 1201(b)(1)$ ) (emphasis added). According to Professor Samuclson, such a research tool might be seen as nonviolative of the DMCA, "[i]n view of its lack of commercial significance and the absence of deleterious effects of the sort that the anti-device provisions were intended to reach ...." Id. (footnote omitted); $c f$. id. at 551 ("Because the copyright owner doesn't have a statutory right to control backup copying, perhaps a . . technology intended to enable 
list of the Act's puzzling conundrums and outright defects. ${ }^{70}$ One central question is relevant here: Should the "device regulation" provisions trump the "privileged use" provisions, or vice versa? Put starkly, the question is whether a circumvention technology deployed to accomplish a privileged use would still run afoul of the DMCA. This is a policy issue tailor-made for the courts. It was, arguably, the central question in the Supreme Court's Sony decision. ${ }^{71}$ In a better world, courts would have conducted the debate in the time-tested forum of copyright's fair use provision. Principles developed over many years would have been brought to bear on this important new set of issues. Perhaps in the end, Congress would have passed legislation largely codifying a general consensus, or at least preserving a workable truce. But alas, that is not our fate-or so it appears. If the copyright inavens are correct, the DMCA has now preempted the unfolding of this drama. ${ }^{72}$ And, they argue, we are all the poorer for it. Digital contentoverprotected at the outset by well-intentioned but imisguided copyright law-may now never reach its full potential to add to the public domain.

This may well turn out to be the case. But, a few words of caution are appropriate here. Even the DCMA's staunchest opponents suggest several ways that the law may permit the process of accommodation that worked so well in copyright throughout the last century. First, the Act itself shows a certain concern for the care and nurturing of those classes of works that are, or may become, adversely affected by the technical protection measures the Act enables. For example, the Act does not take effect right away, giving the Librarian of Congress time to determine an initial set of adversely impacted uses of digital works which are, or are soon likely to be, impacted by the widespread availability of digital protection schemes. ${ }^{73}$ After the initial moratorium, the Librarian of Congress must continue to

[statutorily permissible] backup copying [under 17 U.S.C. \$ 117] should be outside the statute."). These passages suggest a general interpretive strategy: to focus on relationships between circumvention and the rights being circumvented: "to 'circumvent a technological measure' means to descramble ..., decrypt ..., or otherwise to avoid ... a technological measure, without the authority of the copyright owner." 17 U.S.C. $\$ 1201$ (a). Certainly, where technologies are used to protect works that have fallen out of statutory copyright protection, this definition affords a defense: no copyright, no copyright owner, no circumvention. It might even be argued that there is no "copyright" in the unprotectable portions or uses of an otherwise copyrightable work (and thus that there is no "copyright owner" of those portions), though this seems a stretch. This strategy attempts to re-establish the centrality of the circumventer's acts in the inquiry of whether the DMCA's device regulation provisions apply.

70. See, e.g., Samuelson, supra note 58; Benkler, supra note 61; David Nimmer, Puzzles of the Digital Millenium Copyright Act, 46 J. CoPYRIGHT Soc'Y 401 (1999); David Nimmer, A Riff on Fair Use in the Digital Millenium Copyright Act, 148 U. PA. L. Rev. 673 (2000).

71. 464 U.S. 417 (1984). In Sony Corp. of America v. Universal City Studios, Inc., the Supreme Court held that home videotaping of television programs for purposes of "time-shifting," or watching a program after it has been broadcast, was a non-infringing fair use, and therefore that sellers of VCRs were not contributorily liable for infringing program copyrights.

72. But cf. Benkler, supra note 61; infra note 78.

73. See 17 U.S.C. $\$ 1201($ a)(1)(D) (2000). 
monitor the digital landscape, creating three-year exemptions for classes of works newly impacted by technical protection schemes deployed under the Act. ${ }^{74}$ These exemptions may be renewed if circumstances warrant. ${ }^{75}$

In some ways, this merely carries forward (in "statutorified"76 fashion) the common law process described earlier. It may prove troublesome over time, however. We simply do not know how the various interest groups will influence this rulemaking process. At a minimum, this new provision adds to the potential for capture or influence by copyright proprietorsthough it is important, at this early stage, to emphasize the word potential. For it is also possible that the process could come to mirror the more balanced inquiry called for by the statutory fair use analysis. ${ }^{77}$ And, it is worth noting, at least one prominent copyright scholar has argued that the "rulemaking" section of the DMCA provides an independent defense for an accused infringer whose acts should have been, but were not, exempted by the rule. ${ }^{78}$ If this interpretation is accepted by the courts, it will open up the exempt-use rulemaking provisions to a healthy dose of judicial review. ${ }^{79}$

74. See id. Each such rulemaking proceeding leads to publication of rules exempting "any class of copyrighted works for which [the determination has been made] that noninfringing uses by persons who are users of a copyrighted work are, or are likely to be, adversely affected [by the protections of the DMCA] ...."Id.

75. See id.

76. The word is borrowed-fairly, I might add-from GuIDo CALABRESI, A COMMON LAW FOR THE AGE OF STATUTES 1 (1982) (noting the "statutorification" of American law), who in turn borrowed the idea from Grant Gilmore, The Ages of American Law 95 (1976) (speaking of "an orgy of statute-making" in American law).

77. $\$ 107$ sets forth four factors to frame fair use analysis. See 17 U.S.C. $\$ 107$ (1994). Compare Harper \& Row, Publishers, Inc. v. Nation Enters., 471 U.S. 539 (1985), with Campbell v. Acuff-Rose Music, Inc., 510 U.S. 569 (1994).

78. See Nimmer ON COPYRight § 12A.03:

One may thus inquire whether a defendant, whose usage failed to win recognition via the Librarian's publication, can nonetheless urge, as a defense to being held culpable under the Copyright Act for an anti-circumvention violation, that his exploitation should fall within the statutory safe harbor. The wording of the statute here opens the door for a court so inclined to engage in judicial evaluation of the defendant's conduct and the effect of his usage of the subject work. The conclusion emerges from the language that Congress used: "Neither the exception under subparagraph (B) from the applicability of the prohibition contained in subparagraph (A), nor any determination made in a rulemaking conducted under subparagraph (C), may be used as a defense in any action to enforce any provision of this title other than this paragraph." 17 U.S.C. $\$ 1201(\mathrm{a})(1)(E)$. From that wording, even a defendant who has failed to win publication under subparagraph $(C)$, but who convinces a court that he qualifies for the exception under subparagraph (B), is forbidden from urging that status under any doctrine of United States copyright law "other than this paragraph." The negative implication is that he is allowed to urge the defense under this paragraph. Given that the paragraph in question is that containing the anti-circumvention ban, the conclusion follows that a defendant may urge his qualification under subparagraph (B), even absent publication under subparagraph (C), as a defense to a charge that he engaged in a wrongful circumvention of a technological measure.

79. Note, however, that exempted uses under the rulemaking provisions have no effect on the prohibition against trafficking in circumvention-enabling devices or techniques; once again, uses may be exempt, but dissemination of cireumvention devices may never be exempt, even if their sole purpose is to permit exempt uses. See 17 U.S.C. $\$ 1201$ (a)(1)(E). 
Even if the text is found inhospitable to the kind of open-ended inquiry familiar from fair use cases, there is one final redoubt to which the courts may retreat: the Constitution. To apply general constitutional strictures-in particular, the Intellectual Property Clause in Article I, section 8, and the First Amendment ${ }^{80}$ - to the application of a detailed copyright statute will involve a voyage into largely uncharted waters. Courts' structural oversight of the intellectual property system has a fairly thin and unpromising history. ${ }^{81}$ Yet commentators with a sense of vision and perspective are increasingly agitating for just such an mitiative. It may well be that an unprecedented constitutionalization of intellectual property law is the only rational response to the new wave of copyright legislation. Commentators have certainly noted that the legislative process in the digital arena is heavily weighted toward the interest of copyright owners. ${ }^{82}$ This is, of course, not enough in itself to trigger a challenge to legislation.

80. See Benkler, supra note 61 , at 417 ("The administrative process, and the exclusion of the anti-device provision from it, mvite First Amendment challenges to the [DMCA].") See also id. at 420 (adding that "the decisions of the Librarian must be subject to heightened First Amendment scrutiny, and ... enforcement of the anti-device provision is unconstitutional unless and until the Librarian makes a determination that no noninfringing uses will be adversely affected by utilization of technological protection measures.)

81. Courts have recently rejected constitutional challenges to IP laws. See United States v. Moghadam, 175 F.3d 1269 (11th Cir. 1999) (upholding federal "anti-bootlegging" statute against argument based on "writings" requirement of Intellectual Property Clause); Eldred v. Reno, 74 F. Supp.2d I (D.D.C. 1999) (upholding twenty-year copyright term extension against argument that it violated "limited terms" language of IP Clause).

82. See, e.g., Note, The Criminalization of Copyright Infringement in the Digital Era, 112 HaRv. L. REv. 1705, 1719-20 (1999) (footnotes omitted):

Thus far, Congress has focused on addressing the concerns of the providers through, among other things, the strengthening of criminal penalties. The industry interest groups have successfully made legislators aware of the problem of piracy, a lobbying effort that has prompted the passage of the new laws protecting copyright owners described above. The tilting of the balance is understandable given that copyright law's development has become increasingly dependent on the lobbying efforts of large industries with a financial stake in the legal regime. Some commentators have gone so far as to posit that Congress has encouraged a policy of adopting the copyright legislation agreed upon by certain interested groups through negotiation and compromise among the groups themselves. The disadvantage of this approach is that it ignores the interests of the group that in the aggregate is most affected by such legislation: the public. In theory, legislators represent the public interest; however, in the case of copyright law, legislators seem to have abandoned this responsibility. Although the DMCA did undergo extensive revision and included input from groups such as the Digital Future Coalition (DFC), the interest of the general public was systematically underrepresented.

See also Benkler, supra note 61, at 421; Samuelson, supra note 58, at 523:

[B]y colorful use of high rhetoric and forceful lobbying, Hollywood and its allies were successful in persuading Congress to adopt the broad anti-circumvention legislation they favored, even if it is now subject to some specific exceptions that respond to some concerns raised by Silicon Valley firms and their allies in the legislative process.

Cf. Daniel A. Farber, Free Speech Without Romance: Public Choice and the First Amendment, 105 HARV. L. REv. 554, 561 (1991) (arguing that lobbying by producers of information is likely to be "a less effective proxy for consumer interests than are the efforts of producers in other industries" because "sales of information do not fully reflect the ultimate social benefit of information production," which suggests that the government is more likely to overregulate speech). 
But, as I argue in the Conclusion, we must at least consider the need for stepped-up judicial intervention to redress pure rent-seeking when it does occur.

\section{II}

\section{TRADEMARK LAW}

Trademark law is usually thought to be unrelated to technological change. In this respect, it differs from patent law, where new technology is the essence of the enterprise. Trademark law differs as well from copyright law, which, as I argued earlier, bears the imprint of many successive waves of technological innovation. In fact, conventional wisdom would have it that trademark law has long been an odd fit in the great triumvirate of intellectual property. ${ }^{83}$ Domain names and Web site addresses on the World Wide Web may well have changed all this. Though it still differs from copyright and patent conceptually, contemporary trademark law at least has this in common: it has now been thrust into the same disorienting game of catch-up with which the other branches of intellectual property have long been familiar.

There is no denying that the rapid rise of the Internet has opened a dynamic new chapter in the history of trademark law. Yet, this history is hardly a stranger to technological change. Trademark law-at least in its federal, statutory form-is a product of the slow but steady growth of national distribution and advertising in the late nineteenth and early twentieth centuries. Thus, standardized manufacturing and centralized distribution, both of which in turn depended on numerous interrelated technological mnovations, are really at the heart of moderu trademark law.

\section{A. Mass Consumer Markets and Trademarks}

Just as early trademark law emerged out of the growing mercantile economy of sixteenth-and seventeenth-century Britain, ${ }^{84}$ modern trademark

83. See, e.g., Mark A. Lemley, The Modern Lanham Act and the Death of Common Sense, 108 YALE L.J. 1687, 1694 (1999).

84. See Keith M. Stolte, How Early Did Anglo-American Trademark Law Begin? An Answer To Schechter's Conundrum, 8 Fordham Intell. Prop. Media \& EnT. L.J. 505, $541-43$ (1988) (discussing Sandforth's Case, Cory's Entries, BL MS. Hargrave 123, fo. 168 (1584), reprinted in abstract form in J.H. BAKER \& S.F.C. MiLSOM, SOURCES OF ENGLISH LEGAL History - PrIVATE LAW To 1750 615-18 (1986); HLS MS. 2071, fo. 86, which Stolte sees as the long-sought answer to trademark theorist Frank Schechter's "conundrum" conccrning the origins of trademark law). See also Frank Schechter, The Historical Origins of the Law Relating to Trademarks (1925). According to Stolte:

The sixteenth century brought to England a tremendous growth in commerce and the economy. In fact, during this period, England experienced so much progrcss in its intcrnal economy as well as its development of external markets that the century "amounted to a sort of Industrial Revolution." .... [T] he century saw a rise in local markcts, the increasing availability of consumable goods, and a significant escalation of exports to the continent and other parts of the world. New inventions and technological advances vastly expanded 
law emerged with the expanding consumer economy of the late-nineteenthcentury. ${ }^{85}$ According to business historian Alfred Chandler, new manufacturing and processing technologies, coupled with expanded transportation networks, fueled the growth of late nineteenth-century consumerproducts firms. ${ }^{86}$ In industries as diverse as cigarettes, grains, canned goods, and soap, innovations in processing and packaging made feasible large-scale production and thus national distribution. ${ }^{87}$ Sharp-eyed "firstmovers" quickly seized the opportunity to transform what had been regional, commodity goods into the first true national brands. ${ }^{88}$ According to Chandler, "[a]ll the new enterprises reinforced their first-mover advantages by spending much of the income resulting from the cost advantages of scale on massive national advertising campaigns." ${ }^{\circ 9}$ And so were born many of the brands still recognized by consumers today: Quaker Oats, Campbell Soup, Heinz Ketchup, Libby canned vegetables, Proctor \& Gamble soap products, Colgate products, Swift meats, ${ }^{90}$ and Pabst, Schlitz,

Britain's industrial capabilities, thereby increasing the production and distribution of goods throughout the realm and beyond. .... Local craftsmen and artisans made way for a new class of businessmen, the merchant-adventurers. As a result of this and the vast expansion of industry and foreign trade in general, the guilds, which had theretofore dominated as the regulating force in the English economy, began to decline in membership and influence. Schechter demonstrated that it was the guilds that regulated the earliest form of "trademark law" in Great Britain. It is highly probable that the decline of the guilds, the escalation of the powers of the general government, and the growing influence of the merchant-adventurers in the English economy converged at this period in removing the regulation of trademarks from the "guild jurisprudence" to the common law courts. With the guilds in decline, the plaintiff in Sandforth's Case, and potentially others like him during the sixteenth century, probably viewed the common law courts as a more appropriate forum for obtaining relief against a trademark pirate. "J.G.," or whatever his name may have been, could expect the courts of that period to render a judgment that made sense in light of the economic and commercial context of that time. As the Industrial Revolution of the nineteenth century made it imperative to extend substantial legal protection against trademark infringement and unfair competition, so too did the earlier, more contained "Industrial Revolution" of the si xteenth century.

Stolte, supra at 54I-44 (footnotes omitted).

85. Changes in packaging technology played a role in the growth of trademarks as well. See PHIL

PATTON, MADE IN U.S.A. 21 (1992):

With the invention of the machine-made container, the familiar printed packages of what, beginning in the $1880 \mathrm{~s}$, would become national brands followed: National Biscuit's Uneeda Biscuits, Kellogg's cereals, soap powders such as Sapolio and Gold Dust, and previously bulk products like Quaker Oats. With such commercial changes, packaging had superseded packing: the container and the contained entered into a new sort of relationship. Packaging changed what was inside, implied a special status for what might previously have been a generic product- "branded" it into something different.

86. AlFred D. Chandler, JR., SCALE ANd SCOPE: The DyNamics of INdustrial Capitalism 63-65 (1990).

87. See id. at 63-65.

88. See id. at $168-70$.

89. Id. at 65 .

90. Swift is a good example of a regional agricultural processing firm that became a national consumer products firm. Swift Packing integrated forward from its beginning as a slaughterhouse until it became a full-fledged national frozen meat company. According to historian Peter George:

Swift saw new opportunities for the marketing of meat products with the development of the refrigerated railroad car, which after 1878 permitted the marketing in eastern cities of refrigerated meat that had been slaughtered and dressed in the Midwest. . . . Swift created a 
and Anheuser Brewing beers. ${ }^{91}$

With these developments in mind, it is no surprise that agitation for the first national trademark legislation appeared in the 1870s. Earlynineteenth-century trademark cases were based on general common law principles growing out of the law of fraud. ${ }^{92}$ The gradual evolution of what might be called consumer fraud, into a general body of unfair competition law was well under way by this time. But common law was state law, and this was thought to be an inadequate basis for the emerging national brands that grew out of the late-nineteenth-century trends documented by the business historians. ${ }^{93}$ It makes perfect sense, then, that when an enforceable national trademark law was finally enacted in 1905 it was premised on the constitutional power to regulate interstate commerce.

The first attempt at federal legislation had been rooted in the Patent and Copyright Clause of the Constitution, and for this reason had been

national distribution and marketing orgauization around a network of midwestern branch plants where the livestock slaughtering and packing was done.

Peter George, The Emergence of Industrial America 83 (1982).

91. ChANDLER, supra note 86 , at 64-65.

92. Common law unfair competition cases demonstrate that fraud or deceit was the original touchstone for this body of law. In a typical case, a merchant, call him $A$, began selling goods bearing a trademark associated with another, $C$. The real victims of the infringement were consumers, $B$. The law of unfair competition conflated $B^{\prime}$ 's and $C$ 's discrete harms into a single cause of action. It in some sense allowed $C$ to stand in $B$ 's shoes and sue $A$ for misrepresentation. See Kenneth J. Vandevelde, The New Property of the Nineteenth Century: The Development of the Modern Concept of Property, 29 BuFF. L. REv. 325, 341 (1980). In the eighteenth century, trademarks were protected only by the common law of fraud; beginning with Millington v. Fox, 40 Eng. Rep. 956 (Ch. 1838), where a tradesman was permanently enjoined from using another's mark, dicta began to appear suggesting that marks were a form of property. Further support for the notion that trademark law served primarily to prevent consumer fraud can be found in Mira Wilkins, The Neglected Intangible Asset: The Influence of the Trademark on the Rise of the Modern Corporation, 34 Bus. \& HIsT. 66, 72 (1992) (writing that "in the American colonies laws passed to maintain the quality of manufactured articles came to form the basis of the country's subsequent trademark legislation. . . . [B]ut not until the late 1840s was the first state law passed "to prevent fraud in the use of false stamps and labels"').

The Act of 1905 eliminated the requirements of identicality and intention to deceive, substituting instead the more fluid test of likelihood of confusion. The Lanham Act further liberalized trademark law by providing advantages to registration of trademarks and introducing a separate statutory prohibition against "unfair methods of competition" that afforded protection even to unregistercd marks. See 15 U.S.C. $\$ 1125$ (a) (1994). The result is that a broad class of "marks" now qualify for Lanham Act protection. Individual consumers are isolated, and each generally purchases only a few of a given trademarked item. Especially by the time interstate transportation is elaborate, an individual consumer has very little incentive to police trademark infringements. The collective action problem in forming a class for purposes of class action remedies is simply too great. Competitors, however- $C$ in the story here-have a much greater incentive to police misuse of their marks. On this view, the legitimate trademark user's lower transaction costs in policing the mark are harnessed to the original, fundamental consumer protection rationale to obtain the modern trademark infringement suit. Trademark "ownership," on this view, essentially begins as something like a legal fiction, which gives the trademark user a cause of action she would not otherwise have, in order to benefit consumers and the competitive process.

93. See J. Thomas McCarthy, 1 McCarthy on TRademarks and Unfair Competition $\S 5.3$ (1998 \& Supp. 1999) (describing the provisions of the 1881 Act as "inadequate"). Obviously, if the federal act was inadequate, so was the body of common law rules it was meant to augment. 
struck down by the Supreme Court in $1879 .{ }^{94}$ The holding said a great deal about nineteenth-century conceptions of trademark law. The opinion stressed that although a trademark was a property right, the property was only the culmination of a long-germinating set of associations. ${ }^{95} \mathrm{~A}$ trademark vested only after consumers came to associate a trade name with a particular product. As the Supreme Court pointed out, this made a trademark a different sort of thing entirely from a copyright or patent. ${ }^{96} \mathrm{It}$ was not a reward or inducement for something new and valuable; it was a capstone cementing a tight bond between a trade name and a product.

If the nature of the right was different, the constitutional basis would have to be different as well. Trademark legislation was enacted after the Trade-Mark Cases on the basis of the Constitution's Commerce Clause, rather than the Patent and Copyright Clause. ${ }^{97}$ For this reason, the first federal legislation applied only to international commerce, however. ${ }^{98}$ According to leading trademark authority J. Thomas McCarthy, "[f]or twentyfour years American business chafed under the totally inadequate provisions of the 1881 Act." ${ }^{\text {"99 }}$ During this period, federal statutory law did not apply to interstate commerce, and the growing consumer-oriented businesses had to make do, for the most part, with common law protections. The federal statute did provide for federal registration, however-which opened the way for rival trademark claimants to use the Trademark Office as an administrative tribunal for settling what were essentially domestic priority disputes. ${ }^{100}$ At the same time, the federal common law of trademarks seemed to operate as a reasonable stopgap measure. Emerging consumer goods giants such as Coca-Cola and Nabisco undertook massive enforcement campaigns even before Congress passed the first effective federal protection in $1905 .{ }^{101}$ At a minimum, pre-1905 law was not a complete disaster: witness the effective policing efforts surrounding such early

94. See The Trade-Mark Cases, 100 U.S. 82 (1879).

95. See id. at 94 .

96. See id. at 93-94 ("Any attempt, however, to identify the essential characteristics of a trademark with inventions and discoveries in the arts and sciences, or with the writings of authors, will show that the effort is surrounded with insurmountable difficulties.").

97. See McCARTHY, supra note 93.

98. See Act of Mar. 3, 1891, 26 Stat. 1106 (1881).

99. See McCARTHY, supra note 93, at \$ 5.3.

100. See The Coca Cola Company, Opinions, Orders, Injunctions, and Decrees Relating TO UNFAIR COMPETITION AND INFRINGEMENT OF TRADEMARK 529-34 (1st ed. 1923) (setting forth records in 1892 trademark opposition between Coca Cola Co., one "Beermann," and one "Kent," on attempts to register, respectively, "Co-Co-Colian" and "Coca-Cola").

101. See National Biscuit Company Trademark Litigation 7-9 (5th ed. 1915) (avail. Boalt Hall law library) (setting forth court judgment in National Biscuit Co. v. Thomas, C.C.N.D. Ill. 1899 ("Iwanta" brand biscuit infringed "Uneeda" trademark)); The Coca Cola Company, supra note 100, at 634 (list of trademark registrations in forty-three states; two federal registrations; many foreign countries). 
household name trademarks like Uneeda Biscuits and Coca-Cola. ${ }^{102}$ In cases against the many would-be freeriders on the already powerful CocaCola trademark, for example, the Coca-Cola company invoked trademark principles arising from the common law that seemed natural to the courts, and which seem in some ways little different from their current statutory einbodiment in the Lanham Act. ${ }^{103}$

The 1905 Trademark Act-also preimised on the Commerce Clausefinally reınedied the situation, bringing clarity and uniformity to trademark law in accordance with the needs of the burgeoning consumer-products industries. ${ }^{104}$ Yet the pre-1905 era, as we have seen, had not been completely devoid of effective legal responses. My point is not that the 1905 Act was unnecessary. Instead, I argue simply that the law had developed soine fairly effective stopgap measures in the years between the emergcnce of large-scale distribution for consumer products and the birth of a comprehensive federal scheme for the protection of trademarks. In sum, pre1905 federal and state common law were very likely far from optimal. Yet they were also no disaster. Once again, the legal system seems to have coped reasonably well with this massive change in economic conditions.

\section{B. Domain Names}

In 1900, trademark law was a limited body of state and federal common law, just beginning to adjust to its key role in facilitating nationwide commerce. The changes came slowly, first with the 1905 Act, and then with a growing body of law directed to the new economy. Some important early cases centered around conflicts between two types of trademarks: local or regional marks, and emerging national brands. ${ }^{105}$ Overall, the law accommodated the interests of both types of trademarks. But, as Congress intended, the law usually gave an advantage to the national brand, at least to the extent that actual nationwide distribution was accompanied by registration of the trademark on the centralized register in the U.S. Trademark Office. ${ }^{106}$ Congress reconciled limited, regional "common

102. Their success is demonstrated by the survival of these household name brands as valid trademarks for many years, notwithstanding the vagaries of state-by-state protection.

103. See The CocA Cola Co., supra note 100; $c$. Ohio Baking Co. v. National Biscuit Co., 127 Fed. 116 (6th Cir. 1904) (distinguishing between federal trademark law and state common law of unfair competition, though applying general principles of both in case).

104. Act of Feb. 20, 1905, 33 Stat. 724, 15 U.S.C. $\$ \S 81-134$ (1905) (repealed 1946) (“An Act to authorize the registration of trade-marks used in commerce with foreign nations or among the several States or with Indian tribes, and to protect the same.")

105. See, e.g., Coca-Cola Co. v. Nashville Syrup Co., 200 F. 157 (D. Tenn 1912), aff'd, 215 F. 527 (6th Cir. 1914) (enjoining defendant's use of infringing "Fletcher's Coca Cola" labels, though labels did not copy plaintiff's script and sales were limited to Tennessce).

106. National registration saved trademark owners the bother of successive statc registrations, and permitted expansion of trade into all areas where no pre-existing similar marks had been in use. See United Drug Co. v. Theodore Rectanus Co., 248 U.S. 90 (1918). 
law" use, and (at least potential) nationwide use under federal legislation, in the Lanham Act of 1946. ${ }^{107}$ The Lanham Act also consolidated and restated case law on a number of iinportant issues, from priority in registration to the "likelihood of confusion" standard for tradennark infringement.

One seemingly minor aspect of trademark practice was also codified in the Lanham Act, the law dealing with transfers of trademark rights, which generally fall into two categories: outright sale of a business, and trademark licensing. ${ }^{108}$ The Act inodernized the law of business sales that include a trademark, by clarifying the old common law requirement that some of the assets of the business must be transferred along with the trademark. ${ }^{109}$ It also clarified that trademark licensing was a perfectly lawful activity, ${ }^{110}$ subject to one caveat: the licensor of a trademark was required to supervise the activities of its licensee(s), so as to assure consumers that it was maintaining whatever goodwill had accumulated around a trademark. ${ }^{11}$

These provisions dispelled some lingering concerns, left over from scattered cases at common law, that trademark licensing was somehow anathema to the foundational premises of this body of law. ${ }^{12}$ The older

107. Generally, federal registration provides constructive notice to all would-be competitors that nationwide trademark rights are claimed. Prior local users of a trademark can continue local use, but cannot in general expand that use. See generally MERgES ET AL., INTELLECTUAL PROPERTY IN THE New TechNological Age 628-31 (2d ed. 2000).

108. See Lanham Act $\S 5,15$ U.S.C. $\S 1055$ (1994) ("Uses by related companies affecting validity and registration"); Lanham Act § 10, 15 U.S.C. \$ 1060 ("Assignment of mark").

109. See 15 U.S.C. $\$ 1050$.

110. Prior to the passage of the Lanham Act, many courts took the position that the licensing of a trademark separately from the business in connection with which it had been used worked an abandonment of the mark, thus terminating the licensee's trademark rights. See, e.g., Reddy Kilowatt, Inc. v. Mid-Carolina Electric Cooperative, 240 F.2d 282, 289 (4th Cir. 1957).

111. Lanhant Act §5, 15 U.S.C. § 1055:

Where a registered mark or a mark sought to be registered is or may be used legitimately by related companies, such use shall inure to the benefit of the registrant or applicant for registration, and such use shall not affect the validity of such mark or of its registration, provided such mark is not used in such manner as to deceive the public.

And 15 U.S.C. $\$ 1127$ defines related company to mean "any person whose use of mark is controlled by the owner of the mark with respect to the nature and quality of the goods or services on or in connection with which the mark is used."

112. See, e.g., American Broadcasting Co. v. Wahl Co., 121 F.2d 412, 413 (2d Cir. 1941) (trademark license for radio quiz show "Take It or Leave It" was invalid as an assignment in gross, there having been no transfer of underlying business assets in conjunction with the license; "[a] license of a trade-mark that has never been connected with the business of the licensee is objectionable for the same reason as an assignment of a trade-mark in gross and transfers no rights."). The rationale was laid out thoroughly in an earlier case, Lea v. New Home Sewing Mach. Co., 139 F. 732, 733-34 (C.C.E.D.N.Y. 1905):

Neither as to the origin of the article, the place of manufacture, the concern, corporation, firm, or person by whom manufactured, or the transferee thereof, or the connection of the plaintiff therewith, did the label state to purchasers, when used under the license, what it was capable of stating when used by the plaintiff [on machines of its own manufacture]. It was a license to use a stamp, dissociated and stripped of truth and of its former significance, for the 
cases expressing this thought were steeped in the idea that trademark law protected consumers' associations between a particular name or logo and a specific business establishment, located in a specific place, and selling one specific line of goods. These sentiments, while no doubt reflective of the eighteenth-century economy that spawned them, were quite out of step with the growing mass consumer market of the twentieth century. And so they were put to rest in the Lanham Act.

And thus a series of small doctrinal modifications found their way into the Lanham Act, with the overall effect of liberalizing trademark usage across related firms. These changes embraced both multi-plant, national brands, which were produced at regional factories for regional distribution, as well as the outright licensing of trademarks to independent firms. In time, the latter practice grew, as new modes of corporate organization developed. In retrospect, we can see that this liberalization of trademark licensing had very important consequences for twentiethcentury commerce. In particular, secure trademark licensing helped usher in two important commercial practices with significant economic repercussions: (1) national franchising, and (2) so-called character and merchandise licensing. ${ }^{13}$

Although new, trademark-dependent organizational forms were rapidly evolving, trademark law itself changed only incrementally after 1946. The most significant developments were (1) greater protection of trade dress (trademark protection for the shape and appearance of a product's packaging or the product itself), ${ }^{114}$ and (2) the spread of state antidilution protection (under which plaintiffs have a cause of action even where there is no direct competition between plaintiff's and defendant's goods). ${ }^{115} \mathrm{Al}-$ though both of these changes raise fascinating questions, they were of a piece with the earlier history of trademark law this century: incremental changes, part of the broader trend toward stronger trademark rights, but hardly revolutionary.

purpose of falsely inducing purchasers to believe that what it meant when used by the plaintiff it meant when uscd by the defendant. At the earlier time the stamp meant that the plaintiff had contributed something of value to the article; at the later time it purported to mean the same thing, but spoke falsely. It is considered that the facts alleged in the complaint do not show a valid license to use a trade-mark.

See also 2 Thomas J. McCarthy, McCarthy on Trademarks AND Unfalr Competition $§ 18: 39$ (4th ed. 1996 \& Supp. 1999).

113. Character and merchandise licensing relates to the very active markct for the use of logos, cartoon characters, and so forth, on all manner of consumer products.

114. See Robert P. Merges et al., Intellectual Property in the New Technological. AGE (2d ed. 2000), at Chapter 5 (Trademark and Trade Dress). For a modern example of the scope of trade dress protection, see Two Pesos, Inc. v. Taco Cabana, Inc., 505 U.S. 763 (1992) (restaurant decor).

115. See Elliott B. Staffin, The Dilution Doctrine: Towards Reconciliation with the Lanham Act, 6 Fordham Intell. Prop., Media, ANd ENT. L.J. 105, 107 (1995) (collecting state dilution statutes). 
The very recent history of trademark law, however, is just the opposite. Trademark law today is being asked to change very rapidly in response to the sweep and swirl of a major new technology, the Internet. In just five years, trademark law has become suffused with issues concerning Internet domain names. ${ }^{116}$ While it is too dramatic to say that trademark law will never be the same-it adjusted well to the emergence of mass consumer culture earlier this century, after all-it is safe to say it has never changed so fast. That is because Internet technology has two features that implicate core trademark issues at every turn: (1) instant, worldwide accessibility, connecting the party at every Internet address with a potentially worldwide market; and (2) a technical design that includes unique addresses as a critical feature, which puts a premium on short, memorable words, phrases, and mnemonics, turning many effective Internet addresses into contested quasi-trademarks. These features have brought trademark law into the forefront of areas of IP law grappling with the legal implications of the spread of Internet and electronic commerce.

To date, tradeniark law has adapted to Internet technology in two fundamental ways. First, in decisions regarding the legal significance of domain names under trademark law's traditional principles; ${ }^{117}$ and second, in decisions concerning what has become known as cybersquatting. ${ }^{118}$

The initial question for trademark law has been what, if any, legal import is there to use of a particular domain name? The answer-reassuring for many trademark attorneys - has been crafted using conventional, wellunderstood legal principles. The essence of the analysis to date has been to view a domain name as just another "name, symbol, [or] device," listed in the Lanham Act's definition of a trademark. ${ }^{119}$ The fact that a domain name is a unique address in cyberspace is irrelevant, in and of itself; the miportant issue has been what sort of goods this address is attached to, that is, what appears at the unique address? An address attached to informational material may be registered as an online magazine, for example. Likewise, there may be no change in legal status when a trademark for a well-known brand name is appended with the "dot com" address indicator, especially if

116. See generally Jennifer Golinveaux, What's in a Domain Name: Is "Cybersquatting" Trademark Dilution?, 33 U.S.F. L. REv. 641 (1999) (reviewing cases).

117. See Cybersell, Inc. v. Cybersell, Inc., 130 F.3d 414 (9th Cir. 1997) (bona fide trademark dispute between two entities that both wanted to use the same trademark online); Avery Dennison Corp. v. Sumpton, 999 F. Supp. 1337 (C.D. Cal. 1998) (dilution claim involving Internet domain names where defendant had registered and allegedly wanted to sell to plaintiff domain names closely associated with plaintiff's well-established business).

118. See, e.g., Panavision Int'l v. Toeppen, 141 F.3d 1316 (9th Cir. 1998); In First Cybersquatting Dispute Decision, WIPO Orders Registrant to Hand Over Name, PAT. TradeMaRK DAlly (BNA), Jan. 18,2000 (describing WIPO dispute resolution panel decision involving blatant cybersquatter).

119. See, e.g., Brookfield Communications v. West Coast Entertainment Corp., 174 F.3d 1036 (9th Cir. 1999) (federal registration of MovieBuff trademark gives owner rights against later user who secured use of domain name moviebuff.com). 
the address reveals only an online presence for the brand consisting of promotional material, graphics, and the like. The existing registration may already cover this use of the trademark. The point is that trademark law has in the main avoided the blinding novelty of the Internet, and integrated it in a rather straightforward fashion into the main fabric of this body of law.

The second area where trademark law has responded to the advent of the Internet centers on cybersquatting. This inexact (and inelegant) term covers a multitude of sins, and perhaps some virtues as well. In brief, cybersquatting is the practice of securing Internet domain names and selling the right to use them to others. Cybersquatting is most offensive when it is used as a pure rent-seeking ploy: company A builds up a worldwide brand name, call it Neptune for candy bars; then person B, more Internetsavvy, or quicker-acting than company A, secures the Neptune.com domain name and offers it for sale to A. Trademark law moved swiftly to cut off this naked rent-seeking ploy, and in so doing showed an important degree of adaptability to the emerging Internet technology. ${ }^{120}$

A variant on these facts presents more difficult questions. When a domain name entrepreneur secures a variety of names that are close to, but not identical with, a well-known brand name, a rent-seeking motive may still underlie his or her actions. But arguably there is a component of valuable service as well: the entrepreneur may well have exercised imagination and skill in spinning out the variants he or she registers. And the very act of securing multiple variant domain names may constitute a sort of clerical service in favor of company A.

Domain name entrepreneurs also secure domain names that are valuable because they are short, catchy, or easy to remember. Thus, enterprising souls have registered such names as drugs.com, and loans.com. ${ }^{121}$ Here we have a true service, one that does not deserve to be grouped with the rent-seeking activities referred to above. Names such as drugs.com are potentially valuable to many sellers, not just one. Thus, the entrepreneur has not targeted the valuable brand name of a single firm and "held it ransom" in expectation of a payoff. There is no extortion, because there is no sense

120. See Lee Hawkins, Jr., Simple Capitalism or Cyberextortion?, MilwaukEE J. SENTINEL, Mar. 21, 1999, at A1 (describing Texas case preventing cybersquatters from selling various registered domain names, such as microsoftoffice.com to the Microsoft Corporation). Recently, Congress has gotten into the act by passing legislation that prevents rent-sceking domain name registrations for famous individuals as well as corporate brands. See Antieybersqualting Consumer Protection Act of 1999, Pub. L. No. 106-113, app. $\S \S 3001-3010,113$ Stat. 1537 (1999) (to be codified at 15 U.S.C. $\S$ 1125(d) (2000)). See generally Faye Fiore, "Cyber-Pirates" Targeted by Capitol Compromise, L.A. TrMEs, Oct. 26, 1999, at A4.

121. See Charlie Goodyear \& David Lazarus, Tough Luck-Web Address Already Takem S.F. CHRon., Aug. 17, 1999, at A1 (reporting sale of drugs.com domain name for $\$ 800,000$, and expected sale of loans.com for $\$ 1,000,000$ ). As it turned out, $\$ 1,000,000$ for loans.com would have been a bargaim; Bank of America bought the domain name at auetion for $\$ 3,000,000$. See BofA Reveals It was Buyer of $\$ 3$ Million Loans.com Site, SEATTLE Times, Feb. 8, 2000, at D4. 
in which drugs.com naturally or inherently belongs to any particular seller. Indeed, this practice is quite comparable to traditional brand name consulting, a time-honored, for-profit corner of the marketing and merchandising world. ${ }^{122}$ Of course, these names are also likely to be found descriptive or generic, and thus are poor candidates for trademark protection. In this sense, the cybersquatter market may eventually segment into two quite different submarkets: the market for legitimate, easy-to-remember category spanning names such as drugs.com, where early registration does not deprive any firm of its "natural" online address; and the (illegal) market for already-established trademarks, used as domain names. ${ }^{123}$

III

\section{Patent LaW}

Patent law, no less than copyright and trademark, has had to adapt to several major waves of innovation this century. These innovations have produced monumental changes in the fabric of the law. In this Part I review the three I consider most important: (1) the "corporatization" of patent law, following similar trends in industrial research and development (R\&D) in the early years of the century; (2) the consolidation of eighty years' worth of doctrinal adjustment in the Patent Act of 1952; and-most significant of all, in many ways-(3) the creation of the Court of Appeals for the Federal Circuit in 1982.

The forces driving changes in patent law were on a larger scale than the mere development of a single new technology. This is to be expected; after all, individual new technologies are by design a routine matter in the patent system. A patent system forced to change with the advent of each new invention would quickly collapse. Yet the system does change over time. In retrospect, we can trace the changes we see to long-term shifts in structural patterns of research and development. The first of these to occur this century was the corporatization of industrial research and development, which I take up first.

\section{A. Corporatization of Industrial $R \& D$}

In 1885 , only 12 percent of patents were issued to corporations. ${ }^{124}$ Slightly more than one hundred years later, the proportions had completely reversed: by 1998 , only 12.5 percent of patents were issued to independent

122. Landor Associates is one example of a firm that offers these services. See $<$ chttp://www.landor.com> (visited April, 20, 2000).

123. Recently passed legislation further restricts the ability of cybersquatters under U.S. trademark law. See Anticybersquatting Consumer Protection Act of 1999, Pub. L. No. 106-113, app. $\S \S 3001-$ 3010, 113 Stat. 1537 (1999) (to be codified at 15 U.S.C. § 1125(d) (2000)).

124. David F. Noble, America By Design: Science, Technology, and the Rise of Corporate Capitalism 87 (1977). 
inventors. ${ }^{125}$ These two statistics define the end points of a process that, more than any other single factor, drove changes in patent law over the past one hundred years. As the twentieth century progressed, inventions were more and more likely to be the product of large-scale corporate $R \& D$ rather than of the lone workshop tinkerer. ${ }^{126}$ The newer form of corporate $\mathrm{R} \& \mathrm{D}$ not only brought more hands into the inventive process, ${ }^{127}$ but also made available large pools of concentrated capital, and freed corporate inventors from the onerous task of constantly raising new money to finance research. ${ }^{128}$ Altogether, the consequences of this process were pervasive and deep-and much too complex to detail in a survey article. ${ }^{129} \mathrm{~A}$ couple of points on the main effects will follow.

The rise of corporate inventorship spurred a rapid rise in the volume of patents during the early part of the century. ${ }^{130}$ In response, the Patent Office modernized its operations along a number of important dimensions. At the urging of industry, the Office raised salaries and hired a large number of new examiners. ${ }^{131}$ And with the increase in the volume of patents came the need to more quickly and accurately search the "prior art,"132 and hence the development of modern patent classification. ${ }^{133}$ The same period saw a growing professionalization in the ranks of the patent examiners, including the founding of important professional organizations. ${ }^{134}$ The quiet but effective administrative revolution culminated in the Lampert Patent Office Bill of 1922, which both required qualifications and salaries for

125. U.S. Patent OfFice, OfFicial Annual Report (1998), <hitp://www.uspto.gov/web/ offices/ac/ido/oeip/taf/pat_tr98.htm $>$ (visited April 20, 2000).

126. For a good account, see Leonard S. ReIch, The MaKing of AMERICAN INDUSTRIAL Research: Science AND Business AT GE AND Bell, 1876-1926 (1985). See also David C. Mowery \& Nathan Rosenberg, Paths of Innovation: Technological Change in 20th Century AMERICA (1998), Chapter 2, "The Institutionalization of Innovation," pp. 11-46. For a good description of the cra of "independent inventors" (1870-1920), see Thomas P. Hughes, AMERICAN GeNESIS 13-52 (1989). For a more popular account, replete with details on the vicissitudes of fund-raising, see $\mathrm{L}$. Sprague de Camp, The Heroic Age of American Invention (1961).

127. It should be noted at this point that many historians would emphasize that innovation before the twentieth century was a coliective enterprise, centered in small workshops subject to artisanal or craft-oriented cultural norms. See, e.g., Paul IsRaEL, From Machine Shop to INdustrial LABORATORY (1992).

128. For a discussion of the role of patents in nineteenth century innovation financing, see Naomi Lamaroux \& Kenneth L. Sokoloff, Long-Term Change in The Organization Of Inventive Activity (Papers from a National Academy of Sciences Colloquium on Science, Technology, and the Economy), 93 Proceedings of the National Academy of Sciences of the Unitcd States 12686 (1996).

129. These trends in $R \& D$ were part of a larger pattern of economic concentration in the period 1870-1920. See Olivier Zunz, Making AMErica Corporate, 1870-1920 (1990).

130. See JACOB SCHMOOKLER, INVENTION AND ECONOMIC GROWTH 26 (1966) (growth from 28,000 patents in 1901 to 45,000 in 1935).

131. See NoBLE, supra note 124 , at 102-05.

132. "Prior art" refers to the accumulated publications, patents, and public knowledge concerning technology.

133. See NoBle supra note 124 , at 102.

134. See id. 
examiners, and generally streamlined Patent Office procedures. ${ }^{135}$ By this time, Congress and industry, working together, had largely brought the Patent Office up to date with the faster-paced world of corporate research.

\section{Employee Assignment Agreements}

One important change took place offstage. The rules governing ownership of employee inventions are not part of the federal patent statute. Yet they form an important part of the incentive structure for corporate R\&D. In the late nineteenth and early twentieth century, these rules changed in ways that favored large-scale corporate $R \& D$. First, courts increasingly awarded ownership to corporate employers where R\&D-oriented employees were involved in research. ${ }^{136}$ The second change came after employers began to supplement legal default rules with employment contracts assigming ownership to the corporation. Courts demonstrated an eagerness to enforce these contracts, even where technical defects created plausible doubts about enforceability.

To take one example, consider employees hired to perform general R\&D work. In the absence of a contract, the older cases usually gave ownership of inventions to the employees themselves. ${ }^{137}$ The shift to the modern rule took two forms: the emergence of a default rule in favor of employer ownership for all R\&D employees; and the expansion of employment contract principles to include express and implied assignment of invention rights under these circumstances. ${ }^{138}$ Professor Catherine Fisk describes in detail the shift between 1830 and 1930 from a relatively proemployee legal standard to today's pro-employer rules. One cause of the change in legal doctrine was, she argues, the changing nature of technology and the growth of corporate team research. ${ }^{139}$ Another was the emergence of a pro-employer ideology that followed from these changes. ${ }^{140}$ Surely there is some truth in both assertions. Looking at the technoeconomic setting of employee inventions, it seems evident that the proemployee decisions in the earlier years came predominantly in singleinventor cases involving relatively straightforward inventions such as agricultural implements. The later, more pro-employer, decisions involved more sophisticated technologies: manufacturing machinery, industrial processes, radio condensors, and the like. To the extent that these more

135. Act of Feb. 18, 1922, Pub. L. No. 67-147, 42 Stat. 389 (codified at scattered sections of 35 U.S.C.).

136. See Catherine L. Fisk, Removing the 'Fuel of Interest' from the 'Fire of Genius': Law and the Employee-Inventor, I830-I930, 65 U. CHI. L. Rev. 1127 (1998) (masterful summary of virtually every invention ownership case of the period).

137. See id.; Robert P. Merges, The Law and Economics of Employee Inventions, 13 HaRv. J.L. \& TECH. 1 (1999).

138. See Fisk, supra note 136.

139. See id. at 1141.

140. See id. at 1197. 
complicated technologies involved greater integration of the work of multiple inventors, and of particular inventions with the pre-existing knowledge and production assets of the employer firm, a rule favoring employer ownership makes sense..$^{141}$

\section{Rules for Naming Inventors}

Courts carried this pro-corporate spirit into other areas of patent law. One important example concerns the rules of inventorship. Traditionally, defects in naming inventors on a patent were fatal: patents were routinely declared invalid when the wrong inventors were listed on a patent. ${ }^{142}$ This may have made some sense when coinventors were essentially partners; the rule gave a strong incentive for the party prosecuting a patent application to name other inventors who deserved credit. But the new reality of large inventive teams undermined this rationale in two ways. First, larger groups of coinventors increased the likelihood of inadvertent naming mistakes. It seems harsh to invalidate a patent under such circumstances. Second-and more important-was the ubiquity of corporate ownership: virtually all mventive employees agreed to assign all work-related inventions to the corporate employer. ${ }^{143}$ Thus little harm would result if an inventor were left off a patent, or if another employee (often a supervisor) were listed when his or her contribution to an invention was in fact minimal. Although there remained a significant risk that a patent would be invalidated for this reason, there was also "judicial reluctance to declare a patent invalid for a technicality," according to patent authority Donald Chisum. ${ }^{144}$ In other words, courts were increasingly sensitive to the exigencies of corporate research. One 1923 case captured the thought perfectly:

If a corporation (incapable of being an applicant for a patent) should employ a score of experts in its laboratories to improve the processes and the products of the corporation, it should be of no concern even to the [Patent Office] to prosecute an inquiry and make a specific finding on the question whether the invention was single or joint and just what part each expert took in perfecting the improvements; and surely a stranger, who is taking advantage of the disclosures in the patent, ought not to escape on the contention that the government made a proper grant but erroneously or wrongfully recogmized the wrong person as applicant. ${ }^{145}$

141. See Merges, supra note 137 , at 8 .

142. See, e.g., Smart v. Wright, 227 F. 84, 87 (8th Cir. 1915) ("TT]he machine was the result of the joint thought and action of the two men, Wright and Smart. That being the case, neither of them could secure a valid patent as sole inventor."); see also MCV, Inc. v. King-Seeley Thermos Co., 870 F.2d 1568, 1570 (Fed. Cir. 1989) ("Before the enactment of [current 35 U.S.C.] section 256, patentees and their assignees committed inventorship errors at their peril ....").

143. See Merges, supra note 137, at 2; Fisk, supra note 136, at 1181-97.

144. Donald S. Chisum, 1 Chisum on Patents $\$ 2.04$ (1999).

145. Bestwall Mfg. Co. v. United States Gypsum Co., 290 F. 798, 799 (7th Cir. 1923). 
The 1952 Act codified this impulse with simplified procedures that carry little risk of invalidity on purely technical grounds such as the improper naming of inventors. Today, patents listing many inventors are not uncommon, ${ }^{146}$ and courts frequently apply these well-settled rules to remedy defects in patent inventorship..$^{147}$

\section{Accommodating Patent Portfolios}

A crucial part of the newly corporatized legal landscape fell into place in 1908 when the Supreme Court rejected a nineteenth-century doctrine disfavoring "unworked" patents. ${ }^{148}$ As between a patentee who did not actually implement the claimed invention, and a patent infringer who used the technology to make and sell something, courts tended to favor the latter. This took several forms, ${ }^{149}$ most notably the denial of injunctions, often at the preliminary stage and sometimes even after a full trial.

Courts viewed the owner of a patent covering an invention not actually in use as being at odds with the patent system's constitutional mandate "[t]o promote the [p]rogress of ... the useful [a]rts." 150 The spirit that animates these cases grew from the same sensibility underlying the ancient doctrine of waste: it was a shame to let an idle patent prevent the defendant from using technology to do the great work envisioned in the Constitution. It was perfectly clear to these courts, in other words, that "the progress of useful arts" prescribed an active, direct mission: to bring new technology into actual use as quickly and thoroughly as possible. ${ }^{151}$ Toward

146. See, e.g., Canon Computer Sys., Inc. v. Nu-Kote Int'l, Inc., 134 F.3d 1085 (Fed. Cir. 1998) (patent naming sixteen coinventors).

147. See, e.g., Fina Oil \& Chem. Co. v. Ewen, 123 F.3d 1466 (Fed. Cir. 1997) (suit by employer to settle inventorship dispute imvolving several employee-inventors).

148. See Continental Paper Bag Co. v. Eastern Paper Bag Co., 210 U.S. 405 (1908). Examples of earlier cases showing disfavor to unworked patents include Electric Smelting \& Aluminum Co. $v$. Carborundum Co., 189 F. 710 (C.C.W.D. Pa. 1900) (No. 4,014) (denying injunction despite finding of infringement) and Dorsey Harvester Revolving Rake Co. v. Marsh, 7 F. Cas. 939,945 (C.C.E.D. Pa. 1873) (same).

149. See Westinghouse Elec. \& Mfg. Co., v. Toledo, 172 F. 371, 372 (6th Cir. 1909) (citation omitted):

[The patent at issue] is what is called a "paper patent," in that it has never been used by the appellant, and that though it is in the business of selling electrical controllers. The excuse given for not using it heretofore is that its use would require a motor adapted thereto, and up to this time it has not deemed it best to put such a motor on the market. The validity of the patent, however, is not affected by its nonuser .... But it may be said to have a bearing on its construction. In view thereof the patent should not be given a broad or liberal construction.

See also Hartford-Fairmont Co. v. United States Glass Co., 2 F.2d 109, 110 (W.D. Pa. 1924) (narrow interpretation proper for paper patent).

150. U.S. CoNST. art I, $\$ 8, \mathrm{cl} .8$.

151. See, e.g, Dorsey Harvester, 7 F. Cas. at 945 (C.C.E.D. Pa. 1873):

I am of the opinion the complainant is entitled to a decree; but it ought to be so framed as not to subject the defendants to any avoidable loss or injury. The complainant is not a manufacturer of reaping-machines, so far as appears, and will be adequately protected by the payment of a just compensation for the use of the Dorsey invention. The defendants have an extensive establishment, and a large capital invested in it for the manufacture of 
this end, courts sought to free the defendant's productive energies, yet still recognize the legitimacy of the property right, by coupling the denial of an injunction with an accounting of the defendant's profits-a "reasonable royalty," in other words. ${ }^{152}$

This view of the vigorous role of patents in national progress came into conflict with certain realities of the new $R \& D$ environment. In particular, patents began to play a much larger role in corporate strategy than they had before. As Leonard Reich has documented so clearly using early records from General Electric's corporate R\&D managers, patents were understood to have important uses outside the protection of technology that the firm planned to market. In particular, they were an important strategic weapon in the long-term struggle between a large firm and its equally large, equally well-heeled rivals. ${ }^{153}$ Large-scale $R \& D$ operations were capable of blazing so many new trails that a firm could not always be sure of staying abreast of all the developments its rivals were pursuing. Patents could be the equalizer. A firm that had fallen behind in some crucial respect could use its patents to force its way into a technological area pioneered by a rival. Such a firm could, for example, acquire key improvement patents in the area of its rival's strength, thus forcing a crosslicense. ${ }^{154}$ It could also acquire complementary patents from an independent inventor for the same end. In addition, corporate R\&D managers began to understand that patents could be thought of as "options."155

machines .... A sudden stoppage of it would be disastrous to them, and would not benefit the complainant.

152. See, e.g., Dorsey Harvester, 7 F. Cas. 939; Landis Tool Co. v. Ingle, 286 F. 5, 6-7 (3d Cir. 1923):

Not overlooking the complainant's rights in the monopoly which the law has given him, it should be observed that he is not manufacturing under this patent nor, so far as we have been informed, has he any licenses outstanding. In other words, he is not a competitor of the defendants, nor are the defendants competitors of his, in the manufacture of boring machines. Therefore it would seem that enforcement of the injunction would cause much greater injury to the defendants than benefit to the complainant.

153. See REICH, supra note 126 , at $235-38$.

154. See, e.g., id. at 235 (quoting memo from GE patent strategist Frank Jewell, advocating acquisition of "necessary secondary patents" to "stop the owner of a fundamental and controlling patent from realizing the full fruits of his patent").

155. These portfolio-based strategies are listed and critiqued in a dissenting opinion by Justice Douglas, who wanted to revive the nineteenth-century rule disfavoring unworked patents:

Patents are multiplied to protect an economic barony or empire, not to put new discoveries to use for the common good. "It is common practice to make an invention and to secure a patent to block off a competitor's progress. By studying his ware and developing an improvement upon it, a concern may 'fence in' its rival; by a series of such moves, it may pin the trade enemy within a technology which rapidiy becomes obsolete. As often as not such maneuvers retard, rather than promote, the progress of the useful arts. Invariably their effect is to enlarge and to prolong personal privilege within the public domain." One patent is used merely to protect another. The use of a new patent is suppressed so as to preclude experimentation which might result in further invention by competitors. A whole technology is blocked off. The result is a clog to our economic machine and a barrier to an economy of abundance.

Special Equip. Co. v. Coe, 324 U.S. 370, 382-83 (1945) (Douglas, J., dissenting) (footnotes and citations omitted) (quoting Walton Hale Hamilton, Patents and Free Enterprise 161 (1941)). 
For this strategy to work, however, a firm had to have a credible threat to sue based on its patents. The policy against unworked patents potentially barred the way. If this doctrine stood, firms would be forced into some sort of token use of patented technology to preserve their right to fully enforce their patents. This might prove expensive. ${ }^{156}$ Fortunately for firms pioneering the strategic use of patent portfolios, the Supreme Court rejected the rule disfavoring unworked patents in the 1908 case Continental Paper Bag Co. v. Eastern Paper Bag Co. ${ }^{157}$ In this case, the Court swept aside any notion that a patented invention must be practiced to justify its initial grant or sustain its validity. Although couched in the formalist, "guilded age" style that evoked the austerity of the common law, the opinion was (intentionally or not) actually quite forward-looking. It ratified a number of important corporate strategies that were just then emerging, all of which centered on the use of large patent portfolios. In so doing, it marked an important step on the way to legal recognition of corporate $R \& D$ and invention.

\section{B. The 1952 Patent Act: A Study in Legislative Consolidation}

The three-stage process of legal adaptation described in the Introduction-disequilibrium, adaptation, and legislative consolidationplayed out in patent law just as it did in copyright and trademark. In the preceding paragraphs I described judicial adaptation to the corporatization of research. Many of these adaptations were codified and consolidated in the 1952 Patent Act, the last major overhaul of the patent system.

Consider first 35 U.S.C. $§ 116$, on joint inventorship. The 1879 Act, in force prior to 1952 , did not provide explicitly for this increasingly common situation. According to the authoritative Drafter's Commentary on the new statute, the legal requirement that joint inventors apply for a patent jointly had been derived "by necessary implication" from the old act. ${ }^{158}$ In response, Congress added section 116, "a new section not having a counterpart in the old statute,"159 providing a smoother and more regularized

156. One example is provided in passing by Leonard Reich. He describes a group of GE patents in the area of neutrodynes that had apparently had no strategic value for a number of years. Because of the moves of competitors, however, they became strategically useful, and so they were successfully trotted out. See REICH, supra note 126, at 235. This is one story in Reich's overall account of the strategic use of patents for trading purposes, which of course would be more difficult under a rule disfavoring unworked patents.

157. 210 U.S. 405,429 (1908) ("II]t is the privilege of any owner of property to use or not use it, without question of motive."). The rule has generally held up over time. See, e.g., SCM Corp. v. Xerox Corp., 645 F.2d 1195 (2d Cir. 1981). See generally Brian D. Coggio et al., Damage Control-What an Adjudged Infringer Can Do to Minimize the Resulting Damage, 15 AIPLA Q.J. 250, 255 (1987).

158. P.J. Federico, Commentary on the New Patent Act (originally printed as a preface to 35 U.S.C.A. (1954)), at 27, reprinted in 75 J. PAT. \& TradEMARK OFF. Soc'y 161 (1993).

159. Id. 
process for both initial applications and corrections of inventorship. ${ }^{160} \mathrm{~A}$ companion section, 35 U.S.C. $\$ 256$, empowered courts to administer parallel inventorship correction procedures for patents involved in litigation. Taken together, the changes lessened the threat of patent invalidation due to inventorship error, and generally eased uncertainties regarding joint invention.

Another change in the 1952 Act facilitated an important corporate patent strategy: the acquisition of "blocking patents." As corporate R\&D led to the amassing of large patent portfolios, firms often developed a "blocking position" to counter an industrial rival's strength in a new technology, thus forcing a cross-license or otherwise obtaining leverage in the new area. ${ }^{161}$ The 1952 Act clarified the definition of the legal rights conferred by a patent, thus ratifying the acceptance of blocking patents. Under prior patent acts, a patent gave its owner "the exclusive right to make, use and vend the invention." 162 Courts interpreted this to mean "the right to exclude others from making, using or vending" - a practice necessitated by the existence of blocking patents. Courts understood at an early stage that an improvement patent on some feature of a patented machine could not be interpreted as conferring an actual right to manufacture or use the improved feature. ${ }^{163}$ For doing so would require an infringement of the broad patent on the machine. And so the courts developed the interpretation that what the statute actually envisioned was a negative right: the right to exclude others from use of the invention. This eliminated the implied affirmative right to actually carry into practice a particular invention, yet preserved the exclusivity (and thus the economic incentive) at the heart of the patent right (and indeed, of all IP rights). The "right to exclude" language was plucked from these cases and inserted directly into the language of the 1952 Act, where it now appears in 35 U.S.C. $\$ 154$. One commonly cited case that stated this interpretation, Crown Dye \& Tool Co. v. Nye Tool \& Machine Works, ${ }^{164}$ found its way into the Drafter's Commentary on the 1952 Act: ${ }^{165}$ a clear case of statutory consolidation of judicial adaptation.

The 1952 Act incorporated and extended judicial accommodations inade under the 1870 Act im many other areas as well: the first-ever codification of the "invention" test (in the guise of section 103's nonobviousness

160. 35 U.S.C. $\$ 116(1994)$.

161. See supra notes 154-155.

162. See, e.g., Act of July 8,1870 , ch. $230, \S 22,16$ Stat. 201 , reprinted in 8 Chisum ON PATENTS app. 14.

163. Cf. Robert P. Merges, Intellectual Property Rights and Bargaining Breakdown: The Case of Blocking Patents, 62 TENN. L. REv. 75 (1994).

164. 261 U.S. 24 (1923).

165. See Federico, supra note 158 , at 50. 
requirement); ${ }^{166}$ the statutory approval of patent claims drafted in meansplus-function format; ${ }^{167}$ and the codification of liberalized rules concerning patent misuse in section 271 (d). ${ }^{168}$ These and other changes clarified and sharpened the property right conferred by a patent, often in ways first suggested by federal courts.

In some respects, however, the statute was not simply the capstone to a steady project of doctrinal construction. It overwrote some critical antipatent decisions of the Supreme Court from its most virulent anti-patent era (roughly 1930-1948). ${ }^{169}$ Thus the new section on means-plus-function claims overturned the Supreme Court's 1946 opimion in Halliburton Oil Well Cementing Co. v. Walker. ${ }^{170}$ Likewise, the new section on nonobviousness, though supposedly a mere restatement of existing principles, in actuality contained language aimed specifically at softening certain Supreme Court opimions from the 1940 s, most notably one that had implied patents were available only for the products of a "flash of creative genius."171 A short (and woefully inartful) sentence quietly undid the damage: "Patentability shall not be negatived by the manner in which the invention was made."172

166. J. Giles S. Rich, Laying the Ghost of the "Invention" Requirement, 1 AIPLA Q.J. 26, 33-34 (1972) (noting that one of the underlying policies behind section 103 was "to cut loose altogether the century-old term invention," and replace it with "conditions of patentability").

167. See 35 U.S.C. $\$ 112$ (1994).

168. Id. $\$ 271$ (d) (1994). Patent misuse is a general doctrine that prohibits anticompetitive assertions of patent rights, or "leveraging" of rights via restrictive licensing agreements. In 1988 Congress liberalized misuse, amending section 271 (d) to provide, inter alia, that "conditioning of a license on licensee purchase of unpatented components-a "tie-in"-is prohibited only where the patentee/licensor has market power in the market for the patented product." See Pub. L. No. 100-73 tit. II, § 201, 102 Stat. 4674 (1988). See generally Robert MERGes, PATENT LAW AND Policy 1183-96 (2d ed. 1997).

169. See, e.g., Jungerson v. Ostby \& Barton Co., 335 U.S. 560 (1949) (striking down patent for lack of invention); id. at 572 (Jackson, J., dissenting) ("[T]he only patent that is valid is one which this Court has not been able to get its hands on."); Cuno Eng'g Corp. v. Automatic Devices Corp., 314 U.S. 84, 91 (1941) (adopting higher standard of invention, based on Patents and Copyrights Clause of the Constitution, and stating in dictum that "a flash of creative genius" is required for an invention to be patentable). Justice William O. Douglas seemed especially suspicious of patents. See, e.g., Automatic Radio Mfg. Co. v. Hazeltine Research, Inc., 339 U.S. 827, 839 (1950) (Douglas, J., dissenting) ("But what worse enlargement of monopoly is there than the attachment of a patent to an unpatentable article? When we consider the Constitutional standard [of invention], what greater public harm than that is there in the patent system...?"); see also WAlton HALE HAMilton, PATENTS AND FreE ENTERPRISE (1941) (pointing to corporate abuses of patents and stressing system's contribution to monopoly); Lawrence Baum, The Federal Courts and Patent Validity: An Analysis of the Record, $56 \mathrm{~J}$. PAT. OFF. Soc'Y 758, 773 (1974) ("With the coming of the New Deal ... the political climate became less hospitable to the patent system."). For a critical commentary on this era, from the perspective of an Ayn Rand-style "objectivist," see Simone A. Rose, Patent "Monopolyphobia": A Means of Extinguishing the Fountainhead?, 49 CASE W. RES. L. REv. 509 (1999).

170. 329 U.S. 1 (1946).

171. Cuno Eng'g, 314 U.S. 84. On the origins of $\S 103$, see Robert P. Merges, Commercial Success and Patent Standards: Economic Perspectives on Innovation, 76 CALIF. L. Rev. 803 (1988).

172. 35 U.S.C. $\$ 103$ (1952) (amended 1984). 
And yet these decisions themselves were in some sense anomalous, at least if one takes the long view. The federal courts had for the most part been fairly friendly toward patents, and in general had made efforts to accommodate the sometimes outdated fabric of the law to the new realities of twentieth-century R\&D. Indeed, the next major development in patent law we must examine shows an even greater faith in the ability of federal courts to "get patents right." This was the establishment of the Court of Appeals for the Federal Circuit.

\section{The Federal Circuit}

The establishment of the Federal Circuit in 1982 was ostensibly occasioned by a yearning for increased efficiency and institutional competence. This court, which among other things has exclusive jurisdiction over appeals in patent-related cases, ${ }^{173}$ was created to unify and harmonize patent law. ${ }^{174} \mathrm{~A}$ major goal was to eliminate forum shopping by litigants in patent cases. A unified court would obviously solve this problem, and at the same time bring the benefits of specialization and in-depth knowledge to this complicated area of law.

Just under the surface, however, the creation of the Federal Circuit had a clear substantive agenda: to strengthen patents. The early decisions, under the firm guidance of ex-Marine Chief Judge Howard Markey, did just that. Its decisions quickly touched on all important areas of patent law, from novelty to infringement, from nonobviousness to remedies. ${ }^{175}$ And over time, it has proven to be a more patent-friendly court than its scattered regional predecessors. On both administrative efficiency and substantive grounds, then, the court has been deemed a great success. ${ }^{176}$

An essay such as this is not the proper place for a full accounting of the Federal Circuit's impact to date. Moreover, such an accounting would be wildly premature given the court's still-tender age. Yet I will hazard a few observations about the Federal Circuit, on themes consistent with the overall approach of this Essay. In particular, I will discuss (if in only a general way) the court's decisions concerning arguably the most important pair of technologies in today's industrial landscape: biotechnology and software.

173. See 28 U.S.C. $\$ 1295(a)(1)(1994)$.

174. See Rochelle Cooper Dreyfuss, The Federal Circuit: A Case Study in Specialized Courts, 64 N.Y.U. L. REv. 1 (1989) (summarizing debate leading up to formation of Federal Circuit in 1982).

175. See Gerald Sobel, The Court of Appeals for the Federal Circuit: A Fifth Anniversary Look at Its Impact on Patent Law and Litigation, 37 AM. U. L. REV. 1087 (1988); see generally RoBERT L. Harmon, Patents and the Federal Circuit (4th ed. 1998).

176. See Dreyfuss, supra note 174 , at 185. 


\section{The Federal Circuit and Biotechnology Patents}

The Federal Circuit has decided two main lines of cases of special interest to the biotechnology industry. The first relates to nonobviousness, the second to the law of enablement.

With respect to nonobviousness, observers widely agree that the Federal Circuit has been very generous toward patentees and patent applicants. ${ }^{177}$ The court has held in a series of important cases, for example, that commonly used techniques in the field may produce patentable inventions. ${ }^{178}$ This has quieted fears in the industry that commercially important products created with widely available laboratory protocols would not be able to garner patent protection. As a consequence of these cases, many important categories of biotechnology products are still protected by a steady stream of patents: genes, the proteins they produce, and humanderived variants on both of these. Investment in the industry has responded over time, as venture capitalists have come to realize that novel and commercially valuable inventions will be able to rely on steady patent protection. ${ }^{179}$

Do these cases show that the Federal Circuit has gone too far in protecting the products of biotechnology research? What justification can there be for granting patents on inventions that are, or may be, "obvious" in a technical sense? The answer may be a function of the expense of conducting biotechnology research. ${ }^{180}$ In general, courts have read section 103 as posing a purely technical question that boils down to whether the average reasonably skilled inventor in a field, hypothetically possessing all the information in the prior art, would be able to confidently predict a successful result just prior to conducting a key experiment. ${ }^{181}$ In most cases, this is the extent of the inquiry. But, occasionally courts sneak a peek at another factor: the cost of conducting the research. In certain cases, the skilled inventor might have predicted technical success, but the cost of conducting the key experiment was very high. Courts have at tinies seen this as a

177. See generally Kenneth J. Burchfiel, Biotechnology AND the Federal Crrcuit 86 (1995) (describing Federal Circuit cases applying relaxed standard of nonobviousness).

178. See id. at 139-40 (describing Federal Circuit cases rejecting as irrelevant to nonobviousness an emphasis on the fact that claimed proteins or gene sequences were the result of laboratory techniques well known in the prior art).

179. See Josh Lerner \& Robert P. Merges, The Control of Technology Alliances: An Empirical Analysis of the Biotechnology Industry, 46 J. IND. ECON. 125 (1998).

180. See Arti Kaur Rai, Regulating Scientific Research: Intellectual Property Rights and the Norms of Science, 94 Nw. U. L. REv. 77, 136 (1999) (citing sources regarding the "usually high" cost of biotechnology research).

181. See, e.g., In re Merck \& Co., 800 F.2d 1091 (Fed. Cir. 1986); see generally Robert P. Merges, Uncertainty and the Standard of Patentability, 7 HrGH TECH. L.J. 1 (1992). 
deciding factor, holding in effect that high-cost research justifies a less stringent standard of purely technical nonobviousness. ${ }^{182}$

The same thinking may lie behind the Federal Circuit's biotechnology nonobviousness decisions. We might explain the Federal Circuit's seeming solicitude for biotechnology inventions as a function of the extremely high cost of conducting this type of research, together perhaps with an appreciation of how important patents are in the industry. ${ }^{183}$ I have argued elsewhere that under stringent conditions (assumptions regarding a specific risk-aversion function, specific definitions of high relative cost research, and the like), economic models suggest that lowering the standard of patentability for high-cost research projects makes economic sense. ${ }^{184}$ The Federal Circuit seems to have reached much the same intuition so far with respect to biotechnology inventions.

If I am right about this, it would represent yet another example of intellectual property law's adaptation to a challenging new technology. As in several other cases, we may be observing the court's adaptation of existing rules and doctrines to the conditions created by a new technology.

The second major area of doctrinal inpact has been enablement ${ }^{185}$ and its close cousin, the written description requirement. ${ }^{186}$ These doctrines are of major concern to the biotechnology industry, because it is in part through them that one determines the overall scope of a patent. And, of course, patent scope determines a wide array of crucial issues for a

182. See, e.g., Hardinge Bros: v. Marr Oil Heat Mach. Corp., 27 F.2d 779, 781 (7th Cir. 1928) (fact that patentee and infringer both made long and expensive experiments in an effort to make an oil bumer with a cover on it is evidence that invention was not obvious); Panduit Corp. v. Dennison Mfg. Co., 774 F.2d 1082, 1099 (Fed. Cir. 1985) (fact that patent holder took seven years and spent millions of dollars is evidence that prior art did not render invention obvious), vacated on other grounds, 475 U.S. 809 (1986); Bethlehem Steel Co. v. Nelies-Bement-Pond Co., 166 F. 880, 896 (C.C.D.N.J. 1909) (patentee showed that he spent between $\$ 50,000$ and $\$ 125,000$ "perfecting" his invention; the court, in invalidating the patent, found that the actual expcrimentation was extremely limited, the large amounts of money were spent after the invention was made and were merely to fine tune it; decision implies that had the money been expended for the original research, it would have been relevant); Edoco Technical Products, Inc. v. Peter Kiewit Sons' Co., 313 F. Supp. 1081, 1086 (C.D. Cal. 1970) (the fact that a long and expensive period of experimentation was required to solve the problem was important evidence of nonobviousness), aff' $d 177$ U.S.P.Q. (BNA) 481 (9th Cir. 1973); $c f$. Eli Lilly \& Co. v. Generix Drug Sales, 460 F.2d 1096, 1103 (5th Cir. 1972) (inventor who undertook costly and painstaking research in developing propoxyphene hydrochloride should be rewarded with a product patent; a use patent or process patent would be insufficient incentive and would discourage the inspiration process); Unitcd States v. Ciba-Geigy Corp., 508 F. Supp. 1157, 1168 (D.N.J. 1979) (for patent relating to hydrochlorothiazide, the costly research undertakcn should be rewarded with a product patcnt).

183. See generally The Business of Biotechnology: From the BenCh to the Street (R. Dana Ono ed., 1991).

184. This argument is devcloped in excruciating detail in Merges, supra note 181.

185. See 35 U.S.C. $\S 112$. Enablement refers to the requirement that the patent specifieation must adequately teach a skilled person how to make and use the technology claimed in the patent.

186. See id. The written description requirement goes beyond enablement; it forces an inventor to describe with precision the subset of disclosed technology that he or she intends to claim in the patent's claims. 
patentee, including who must license his or her invention and how many downstream improvement inventions are covered. In simple terms, these doctrines ask whether a patentee has disclosed enough information to justify the patent claims he or she is seeking. Enablement in particular seeks to insure that the claims of a patent are commensurate with the research performed in the laboratory or workshop, and written up in the patent specification.

The early Federal Circuit decisions on questions of patent scope started out in the same vein as those on nonobviousness. They were generally pro-patentee, often finding that fairly broad claims were indeed enabled in the patent specification. ${ }^{187}$ But, in the past few years, a countertrend of note has set in. A recent series of decisions denies a patentee new claims added after an imitial filing date when those claims delimit an invention quite different from the one apparently contemplated by the inventor at the time of the initial filing. ${ }^{188}$ These decisions have been decided under the newly expanded written description requirement, which has become a crucial adjunct to the general enablement test. The idea is that even when a claim is enabled in the initial application, if it delimits an invention different in kind from the invention contemplated (that is, claimed or pointed out) in the original patent application, it is invalid. The opinions show a marked distaste for this switching-of-horses-in-midstream phenomenon, and rely conceptually on the notion that the original application

187. See, e.g., In re Wands, 858 F.2d 731 (Fed. Cir. 1988) (overturning enablement rejection based on heavily empirical nature of monoclonal antibody technology).

188. See, e.g., Genentech, Inc. v. Novo Nordisk, 108 F.3d 1361 (Fed. Cir. 1997); Univ. of Cal. v. Eli Lilly \& Co., 119 F.3d 1559 (Fed. Cir. 1997). For criticism of the rule announced in these two cases, see Janice M. Mueller, The Evolving Application of the Written Description Requirement to Biotechnological Inventions, 13 BERKELEY TECH. L.J. 615, 615-16 (1998):

The Lilly decision may profoundly limit the scope of protection available for new gene inventions; viewed in tandem with recent decisions interpreting the enablement requirement of $\S 112$ of the Patent Act, it represents the latest advance in an ominous trend towards imposition of uniquely heightened patentability requirements for biotechnological inventions. Lilly aptly illustrates the increased widening of the gulf between the norms of the business and scientific communities and the U.S. patent system, as users of the latter come to understand that the patent system no longer reflects the realities of scientific contribution.

For a similar critique, see Michael Delmas Plimier, Comment, Genentech, Inc. v. Novo Nordisk \&

University of California v. Eli Lilly \& Co., 13 BERKELEY TECH. L.J. 149, 160 (1998):

One may ask if the written description requirement should be eased or done away with in DNA cases. Insulin in many species is extremely similar. Their DNAs may be similar enough that perhaps going through and finding the nucleotide sequences of many species would be repetitive, add little of value to the store of knowledge, and waste resources which could be better used for new research. The written description requirement has been confusing. Enablement can serve the role of preventing inventors from claiming too much. Since it is confusing and perhaps unnecessary, the removal of the written description requirement is something to be considered if the current rule turns out to allow only patents that are so narrow that they inhibit the pace of biotech research. 
ought to provide fair notice of the general contours of the invention that will ultimately be claimed when the patent issues. ${ }^{189}$

For patent applicants in the biotechnology industry, these cases have been seen as bad news. ${ }^{190}$ The common complaint is that they require inventors to perform too much routine lab work to flesh out straightforward variants on claimed technology, typically gene sequences or useful therapeutic proteins. ${ }^{191}$ What the critics seem to have in mind is the notion of opportunity cost: though corporate research can sometimes seem like a bottomless pit in terms of personnel and resources, in fact, research projects are finite since there are usually fixed limits to a firm's overall research budget. This means that a research team that spends time making a long series of straightforward variants on a gene or protein of interest must sacrifice other research. Presumably, some of this other research might pay off with a marketable product that could help someone with a disease or medical condition. To summarize the critics' view, then, the Federal Circuit seems (perhaps inadvertently) to have steered biotechnology researchers toward an increasing amount of mundane and repetitive lab work-precisely the opposite of what the patent system seeks to promote. ${ }^{192}$

But putting aside this doctrinal side trip, the Federal Circuit has overall been quite successful at integrating biotechnology cases into the fabric of patent law. Indeed, the vagaries of software and now Internet patents often leave inventors and lawyers wondering how the system could have accommodated biotechnology so well, when it appears to be having so much difficulty with the new digital domains of invention. This is the topic we consider next.

\section{The Federal Circuit and Software Patents}

To tell the full story of software patents in the Federal Circuit, one must go back in time, to the decade before the Federal Circuit Court's establishment. Only by understanding the doctrinal box that the Supreme Court built in the 1970 s can one truly appreciate the achievement of the Federal Circuit in the 1990s.

A patent claiming a computer algorithm first came before the Supreme Court in 1972, in Gottschalk v. Benson. ${ }^{193}$ The finding of invalidity announced by Justice Douglas was not in itself surprising; as we have

189. See, e.g., Gentry Gallery, Inc. v. Berkline Corp., 134 F.3d 1473 (Fed. Cir. 1998), and cases cited therein.

190. See, e.g., Mueller, supra note 188, at 615 ("ominous trend" of written description cases).

191. See Plimier, supra note 188 , at 160 .

192. For an argument that the patent system as a whole-and the law of nonobviousness in partieular-is aimed at encouraging risky, high-uncertainty research, see Merges, supra note 181, at $19-20$.

193. 409 U.S. 63 (1972). 
seen, it was his wont in patent cases generally to find the patent invalid. What does seem surprising now, almost thirty years later, is Douglas's conception of what computer software is all about. Justice Douglas understood algorithms implemented in computer software as pure mathematical abstractions. ${ }^{194}$ This made his decision in Benson an easy one; because algorithms are timeless abstractions plucked in their entirety from nature's library, they are unpatentable. ${ }^{195}$ This is, after all, the treatment that patent law gives to all abstract truths, all "scientific principles," all "products of nature." Once algorithms are equated with "pure mathematics," they are assigned to a category of discovered universal truths. Hence they are unpatentable.

While this view of things made the case an easy one for Douglas, the legacy of Benson-from a legal point of view anyway-was anything but easy. The problem was that the decision was conceptually flawed, if not plain wrong. Great volumes of legal scholarship have documented over the intervening years what common experience also tells us: software is engineered, not discovered. ${ }^{196}$ It is very misleading indeed to equate a piece of software code, written in the " $\mathrm{C}$ " programming language for some prosaic function such as calculating grade point averages or checking a bank balance, with the discovery of Newton's laws of gravitation, or the Pythagorean Theorem. Perhaps it was that software was still relatively novel in 1972, or perhaps Justice Douglas was simply searching for a way to keep this new subject matter out of the clutches of the patent system of which he was so suspicious. Whatever the reason, he made a major mistake.

Yet if Benson was a lawyer's headache, it presented a far less troubling result for the software industry itself. The output of software, however measured, continued to grow and flourish all through the 1970s, and continues its rapid growth through today. ${ }^{197}$ While probleinatic as a subject matter for patents, software as an economic product did just fine. Thus, as legal mistakes go, Justice Douglas's turned out to be less than earth shattering. While thoroughly wrongheaded, Benson left in its wake a thriving, growing industry, employing thousands of people and selling billions of dollars worth of products.

Whether the industry could have done even better with the added incentive of patents, or whether in fact the absence of patent protection was a blessing, are two hypotheses often discussed in the legal literature and the writings of computer programmers themselves. ${ }^{198}$ We shall never know

194. See id. at 65 .

195. See, e.g., id. (interpreting 35 U.S.C. § 101).

196. The literature is summarized in MerGes, supra note 168 , at Chapter 2.

197. See David C. Mowery, The Software Industry, in SourCES OF INDUSTRIAL LeadershIP 13335 (David C. Mowery \& Richard R. Nelson eds., 1999).

198. See MERGES, supra note 168 at Chapter 2 (collecting relevant excerpts and cites). 
with any certainty. Perhaps now that software has been fully integrated into the family of patentable subject matter, we will have something of an answer. Concerning the interim period when software patents were in doubt, however, at least this much can be said: The industry learned to work around the absence of patent protection quite nicely. There was no shortage of technical innovation and new commercial products. Perhaps something about software provided profits ample enough to induce entry and innovation even in the absence of patents. (Certainly there are entire industries that report in survey data that they could do without patents and still be innovative.) Or perhaps the industry simply adapted to the absence of patents, developing industry practices and strategies that optimized the use of other appropriability or recoupment mechanisms. For example, perhaps more firm-to-firm borrowing took place than would have under patents; so long as most firms participated, this might have made sense.

Whatever the causes of the industry's success without patents, the rules cordoning software off from other engineering products were under constant stress in the courts throughout the 1980s and early 1990s. The Supreme Court itself had opened the door somewhat with the Diamond $v$. Diehr ${ }^{199}$ decision in 1981, which upheld the validity of an invention that incorporated software into a conventional industrial process for curing rubber. The Diehr case suggested a legal/rhetorical strategy that lawyers applied with a vengeance in drafting subsequent patent applications: emphasize the fact that software must operate in cooperation with computer hardware. The result of this strategy was a line of patents-still issuing today now that the practice is entrenched-that characterize a particular piece of software code as merely a specific configuration of a "general purpose" computer. Through the magic of this characterization, software is transformed from a written text that issues orders to a piece of hardware, into a very elaborate specification for (temporarily) rewiring a computer. Although I have often been struck by the sheer silliness of this approach, ${ }^{200}$ it has one virtue that I cannot quibble with: legally, it works. Even the most recent foray into these waters, the State Street Bank case described below, seized on the "machine" aspects of the patent claims at issue as one ground for upholding a patent. This was despite the fact that the invention at issue has nothing whatsoever to do with computer hardware; it is a particular method of using computers to conduct a mutual-fund

199. 450 U.S. 175 (1981).

200. As I often say in class when teaching these cases, it sounds like a sophomore philosophymajor argument. It is the equivalent of saying that when I am thinking about the color red, I have a different brain than when I am thinking about the color blue. It is, in other words, so steeped in micromaterialism as to be useful (conceptually) only as a reductio ad absurdum. Yet for the reasons described in the text, it is a useful mechanism for (1) granting patents on an important form of technology, while (2) avoiding an outright challenge to a standing Supreme Court opinion. Hence at the pragmatic level it is very useful. 
investment business. The Patent Office has even recognized the legitimacy of a claiming strategy featuring the fact that software is stored on floppy disks. ${ }^{201}$ These so-called disk claims take the view that what is being patented is a particular configuration or layout of a data storage disk. A strange sort of legal fiction, to be sure, but perfectly understandable in light of the axis that runs from Benson to Diehr.

It was on this axis that the Federal Circuit had to balance. Slowly and carefully at first, and in recent years more boldly, it has paid obeisance to the boundaries of the Supreme Court's doctrinal box while in effect moving beyond it. In a series of opinions it (1) reinforced the effectiveness of claiming strategies emphasizing the machine aspects of software, ${ }^{202}$ and (2) called into question, and then eliminated entirely, a longstanding prohibition on the patenting of business methods (which today, of course, are often implemented on computers). ${ }^{203}$ The upshot is that this important engineering product is now fully patentable, and the software industry has been freed-willingly or not-from the doctrinal box fashioned by the early Suprenie Court opinions.

In fairness, I must acknowledge that the case of software patents does not fit neatly into the three-part progression I sketched in the Introduction. To be sure, the cases started with disequilibrium; but the accommodation phase I describe throughout this Essay was much longer in coming. And statutory consolidation has not occurred at all-yet. ${ }^{204}$ One might argue that in the longer view, the time it took for the law to accommodate software patents-roughly 1972 to the mid-1990s-will seem short. But it is probably more honest to admit that the three-phase process sketched in the Introduction is just too neat and simple to adequately describe every example of legal accommodation to new technology.

201. See In re Beauregard, 53 F.3d 1583 (Fed. Cir. 1995); Richard H. Stern, An Attempt to Rationalize Floppy Disk Claims, 17 J. MARshall J. Computer \& INFo. L. 183 (1998).

202. See In re Alappat, 33 F.3d 1526 (Fed. Cir. 1994) (en banc); In re Iwahashi, 888 F.2d 1370 (Fed. Cir. 1989).

203. See State Street Bank \& Trust Co. v. Signature Fin. Group, Inc., 149 F.3d 1368, 1374 (Fed. Cir. 1998); see also In re Schrader, 22 F.3d 290, 297 (Fed. Cir. 1994) (Newman, J., dissenting) (prohibition on business method patents is "error-prone, redundant, and obsolete").

204. There are some early signs that Congress is moving to address some of the difficult issues raised by software patents. Late in 1999 , for example, Congress passed a limited prior-user exemption to patent liability, which will permit companies that have long used business processes to avoid infringing patents issued on those processes to other firms. See First Inventors Defense Act of 1999, Pub. L. No. 106-113 div. B, $\$ 1000$ (a)(9), 113 Stat. 1536 (codified at 35 U.S.C.A. $\$ 273$ (Supp. 2000)). Industry leaders have also begun to agitate for systemwide reforms to reflect the special problems of Internet and software firms. See Chris Oakes, Amazon Calls for Patent Fix (visited Mar. 23, 2000) <http://www.wired.com/news/technology/> (describing public letter written by Jeff Bezos, President and CEO of Amazon.com, concerning proposal for overhaul of patent system as it applies to software industry). 


\section{Online Business Methods: Byting Off More than They Can Chew? ${ }^{205}$}

The emergence of patents for business methods or concepts, such as Internet airplane-ticket-purchase systems, ${ }^{206}$ represents a new test of the patent system's adaptability. As I have argued elsewhere, ${ }^{207} \mathrm{I}$ am agnostic at this point about whether these patents as a class are worthwhile. In any event, one thing is clear: the increased volume of patent applications stemming from this newly patentable subject matter has pushed the patent system into crisis. It is now crucial to do some hard thinking about an acceptable error rate for issued patents, with an eye toward reducing the number of invalid business-concept patents that are actually issued. In the process, we may gain a new appreciation of the relationship between the Patent Office and private parties. In particular, patent policy must be redesigned to efficiently coordinate the efforts of both groups to achieve the socially desirable end, which is an appropriate expenditure to determine patent validity. Some of these reforms involve restructuring jobs and incentives in the Patent Office. Others involve the parties that suffer most if a firm receives an invalid patent: the firm's competitors. These also tend to be the parties with the best information about patent validity. It is therefore logical, I (and others) ${ }^{203}$ believe, to get those competitors into the patent process as early and deeply as possible. One proven way to do so is to adopt a patent-opposition system in the U.S., inuch like the one currently in place in Europe. Only reforms such as these will lower the incidence of poor-quality patents. And only then will we be able to decide whether patents for business concepts make sense or not.

Of course, administrative changes of this order are typically implemented by statute. And Congress has so far refused to expand the current reexamination system in a meaningful way, let alone seriously consider full-blown oppositions. ${ }^{209}$ This leaves the courts. An additional quantum of

205. Material in this section is drawn from Robert P. Merges, As Many as Six Impossible Patents Before Breakfast: Property Rights for Business Concepts and Patent System Reform, 14 Berkeley TECH. L.J. 577 (1999).

206. U.S. Patent 5,794,207, to Jay S. Walker et al., "Method and Apparatus for a Cryptographically Assisted Commercial Network System Designed to Facilitate Buyer-Driven Conditional Purchase Offers," issued Aug. 11, 1998 (a key patent on which the priceline.com company is built).

207. See Merges, supra note 205, at 577.

208. See, e.g., Craig Allen Nard, Certainty, Fence-Building and the Useful Arts, 74 1ND. L.J. 759 , 764 (1999) (proposing "the implementation of a post-grant opposition proceeding in the PTO wherein a third party, in an inter partes setting, may challenge the issuance of a patent"); Allan M. Soobert, Breaking New Grounds In Administrative Revocation of U.S. Patents: A Proposition For Oppositionand Beyond, 14 SANTA ClaRA CoMputer \& High TECH. L.J. 63 (1998); Mark D. Janis, Rethinking Reexamination: Toward a Viable Administrative Revocation System for U.S. Patent Law, 11 HARv. J.L. \& TECH. 1 (1997).

209. See Intellectual Property and Communications Omnibus Reform Act of 1999, Pub. L. No. 106-113, $\$ 4601-4608 ; 113$ Stat. 1501 (to be codified at 35 U.S.C.). Section 4607 of the Act provides: 
skepticism may be in order when the validity of Internet-related businessmethod patents is at issue, notwithstanding the statutory presumption of validity that applies to all issued patents. ${ }^{210}$ Even so, only a small number of infringement cases reach the courts. And when they do, the Federal Circuit has generally been moderately pro-patentee in most of its positions. ${ }^{211}$ One can only hope that this general trend will soften when it comes to poor-quality Internet business-method patents. If it does not, we can expect a wave of extortionate patent litigation that may, in the aggregate, slow down the growth of this booming new avenue of innovation.

\section{IV \\ THe Road AHead}

This Essay has been sanguine-some would say naively soconcerning IP law this century. My optimism is genuine. But I would like to add some genuinely cautious words as well, lest the reader be left with the false impression that the IP system can do no wrong. To the contrary: I believe that the people and institutions that shape IP law can do a great many things wrong. Current conditions may make this even more likely than at most times during the past century. The likely wrongs I see ahead take two forms: excessive rent-seeking in the legislative process, and excessive caution on the judicial front. I describe each in turn.

\section{A. The First Deadly Sin: "Pigging Out" at the IP Trough}

According to eminent economic historian Douglass North, societies exhibiting property rights allocations that tend to increase wealth are the exception rather than the rule in recorded history. ${ }^{212}$ More often than not, he argues, various interest groups-most notably the government itselfconspire, or at least acquiesce in, a pattern of entitlements that generates little or no incentive for economic actors to engage in growth-imducing behavior. ${ }^{213}$ Interestingly, one of the shining exceptions North sees in history

Any party who requests an inter partes reexamination ... is estopped from challenging at a later time, in any civil action, any fact determined during the process of such reexamination, except with respect to a fact determination later proved to be erroneous based on information unavailable at the time of the inter partes reexamination decision.

Id. $\$ 4607$. Few patent lawyers will be willing to risk a reexamination request for a client, knowing the client will be precluded from arguing the same factual issues in a patent case in district court.

210. See 35 U.S.C. \$ 282 (1994).

211. John R. Allison \& Mark A. Lemley, Empirical Evidence on the Validity of Litigated Patents, 26 AIPLA Q.J. 185 (1998).

212. See Douglass C. North, Institutions, Institutional Change and Economic PERformance 110 (1990) ("Because polities make and enforce economic rules, it is not surprising that property rights are seldom efficient.").

213. See id. at 73 (explaining persistence of inefficient property rights because of the influence of "powerful constituents"). See also Douglass C. North, Government and the Cost of Exchange in History, 44 J. EcoN. HisT. 255 (1984) ("[P]erhaps the main question for the economic historian about 
is the British patent system of the early seventeenth century, which formed the foundation for the U.S. patent system in the next century. ${ }^{214}$ Britain managed both to encourage invention and to rein in the practice of rewarding royal favorites with state-backed monopolies. Both ends were achieved through the Statute of Monopolies of $1623,{ }^{215}$ which prohibited patents for all items except new and useful inventions. ${ }^{216}$

The history of the U.S. patent system represents a lengthy elaboration on this exceptionally pro-growth foundation. But, as North repeatedly cautions us, exceptions such as this are not permanent. Change is a constant in economic life, and this is as true with institutions as it is with technology. There is nothing foreordained about the future of the patent system, or of any other branch of the IP system for that matter.

\section{Intellectual Property Legislation: Political-Economy Considerations}

Intellectual property legislation has, in recent years, become much more important than it was earlier this century. This is in part a reflection of systemic trends: more law in general is created through legislation now than in earlier years. There is more to it than this, however. In particular, it seems to reflect two trends specific to the IP sector: growing economic importance of the underlying assets, and increasing strength of the property rights that attach to them, largely at the hands of the courts.

One measure of the growing importance of IP legislation is a marked increase in Congressional lobbying in this area. There is abundant evidence that lobbyists are focusing more efforts on IP issues, and that industries with strong interest in $\mathrm{IP}$ issues are spending more. ${ }^{217}$ One recent refugee

the premodern world [is] [d]id the interest of state rulers coincide with a set of property rights conducive to economic gowth? By and large, they did not ....").

214. See Douglass C. North, Structure and Change in Economic History 164 (1981) ("1t is only with the Statute of Monopolies in 1624 that Britain developed a patent law.").

215. 21 Jas. I. ch. 31623 (Eng.).

216. For a brief overview, see Edward C. Walterscheid, To Promote the Progress of Science and Useful Arts: The Background and Origin of the Intellectual Property Clatse of the United States Constitution, 2 J. INTElL. Prop. L. 1, 34-35 (1994).

217. Parry, Romani and DeConcini, a Washington, D.C. firm that specializes in IP lobbying, ranked in the top forty in lobbying firm receipts in 1998. See Center for Responsive Politics Web site at <http://www.opensecrets.org/lobbyists> (ranking lobbying firms by annual receipts for 1998); Steve Evans, Capitol Hill Clout, INDEP. Bus. WKLY., Apr. 12, 1996, at 6 (listing Parry, Romani clients "including the Motion Picture Association, the Recording Industry Association, Glaxo, Genentech, and Herbalife International"). This firm employs former Senator Dennis DeConcini, among others; he has been active on behalf of pharmaceutical firm Schering-Plough in their effort to obtain a "private patcnt bill" to extend the life of their extremely lucrative patent on the allergy drug Claritin. See Claritin Maker Hires Top Lobbyists for Patent Bid, Dallas MoRning News, May 14, 1999, at 6A.

Overall, the communications/electronics industry sector has increased its lobbying expenditures dramatically in recent years, according to the Center for Responsive Politics (a public interest watchdog group). As one would expect, copyright extensions and anti-piracy laws are high on the legislative wish list for this sector. 
from the legislative process has described the many ways that copyright interests now try to influence legislation:

Copyright interest groups hold fund raisers for members of Congress, write campaign songs, invite members of Congress (and their staff) to private movie screenings or soldout concerts, and draft legislation they expect Congress to pass without any changes. In the 104th Congress, they are drafting the committee reports and haggling among themselves about what needs to be in the report. In my experience, some copyright lawyers and lobbyists actually resent members of Congress and staff interfering with what they view as their legislation and their committee report. With the 104th Congress we have, I believe, reached a point where legislative history must be ignored because not even the hands of congressional staff have touched committee reports. ${ }^{218}$

By itself, this trend is not necessarily disturbing. After all, if observers are correct, intellectual property now constitutes a crucial set of corporate assets in the new information economy. So it stands to reason that interest groups would increase their spending on lobbying, just as they would in any area with a growing impact on the bottom line. Especially in a complex area such as IP rights, lobbyists must spend a good deal of time educating legislators and their staffs. With this in mind, campaign contributions take on a different cast: they may simply be the price of

The communications and electronics sector, which includes telephone utilities and the computer industry, leapfrogged from fourth place in 1997 to second in 1998, at $\$ 186$ million, with the computer industry alone spending one-third more.

<http://www.opensecrets.org/pubs/bigpicture2000/appendix_b.ihtml>.

218. William F. Patry, Copyright and the Legislative Process: A Personal Perspective, 14 CARdozo ARTS \& ENT. L.J. 139, 141 (1996) (former House Intellectual Property subcommittee staff member). See also Center for Responsive Politics, No lights, no camera, lots of action: Behind the Scenes of Hollywood's Washington Agenda (Oct. 11, 1998) <http://www.opensecrets.org/alerts/v4/ alrtv4n35.html>:

Walt Disney was a company with a mission. With its copyright for Mickey Mouse up in 2003 , Disney wanted to keep the character and the royalties for as long as it could. The company pushed for a law in the 105th Congress that would grant a 20-year extension on all copyrighted works. Congressional Quarterly reported that Disney CEO Michael Eisner made the entertainment giant's position known at an informal June 9 meeting with Senate Majority Leader Trent Lott (R-Miss). A week later, Lott signed on as a co-sponsor to copyright extension legislation-and the very day Walt Disney's political action committee made a $\$ 1,000$ contribution to Lott's campaign committee. On June 25 , Disney made another donation- $\$ 20,000$ in soft money to the National Republican Senatorial Committee.

Last week the House and Senate cleared the copyright legislation for President Clinton's signature-giving Hollywood a multimillion-dollar windfall. The new law allows individual artists to hold copyrights for their entire lives plus 70 years and studios to keep them for 95 years. Educational groups won a limited exception for some copyrighted works. They had fought the bill, arguing longer copyright terms meant more time before materials became part of the public domain, where neither royalty payments, or permission is required. The Motion Picture Association of America contended the bill was necessary to remain competitive with Europe. Hollywood is also pushing for passage of legislation that would ratify two World Intellectual Property Organization treaties that strengthen international copyright laws and prevent piracy. 
access to legislators, the price that must be paid to gain an audience to transmit information. ${ }^{219}$

Nevertheless, in some cases increased expenditures may be cause for concern. Both public choice theory and empirical evidence suggest that some types of intellectual property legislation may be prone to excessive private-interest influence, or rent-seeking. In particular, we can expect bad results, from the general consumer's point of view, when two conditions hold: (1) the benefits of legislation are tightly concentrated on a small number of specific beneficiaries; and (2) the costs are spread over a large number of consumers over a long period of time, in such a way that almost no one bears a significant cost, at least in the short term. ${ }^{220}$ When these conditions hold, there is a risk that the legislative process may yield legislation that seriously shortchanges consumers.

Two examples of recent legislation demonstrate the point. The first involves copyright-term extension, a classic instance of almost pure rentseeking legislation. The second concerns special legal protection for computer databases, ${ }^{221}$ which I will argue is an example where the legislative process has so far prevented passage of a one-sided piece of legislation. The differences are instructive, and will lead to a tentative proposal for more active judicial intervention in IP legislation under the banner of the Intellectual Property Clause of the constitution.

The Sonny Bono Copyright Term Extension Act of 1998 is a prime example of legislation that strongly favored a narrow class of copyright owners, broadly but mildly affected many present and future consumers, was intensively lobbied, and became law with little opposition. ${ }^{222}$ This Act, which extended the existing copyright term twenty years, was the Walt Disney Company's "highest priority" in the 1998 legislative session of Congress. ${ }^{223}$ From an incentive point of view, the Act is virtually worthless;

219. For a review of contemporary political economy theory as it applies to IP legislation, see Robert P. Merges, Intellectual Property and the New Institutional Economics, VAND. L. Rev. (forthcoming 2000) (summarizing, inter alia, the "information / access" campaign contribution paradigm).

220. This insight was first formalized by Mancur Olson in his seminal work, THE LoGic of Collective Action: Public Goods And the Theory of Groups (1965). It has since spawned a large literature, represented for example in the pages of the academic journal Public Choice. For an authoritative recent account, see Kay Lehman Schlozman \& JoHN T. Tierney, Organized INTERESTS AND AMERICAN DEMOCRACY (1986) (empirical research shows that lobbying is most effective when the interest group's goals arc narrow and the legislation involves issues of "lowvisibility" from the general public's perspective).

221. See Collections of Information Antipiracy Act, H.R.2652, I05th Cong. (1998).

222. Pub. L. No. 105-298, 1 I2 Stat. 2827 (1998) (codified in scattered sections of 17 U.S.C.).

223. Hotline (American Political Network), Aug. 12, 1998, at 41. Academics universally decried the Act. See e.g., Steve Zeitlin, Strangling Culture with a Copyright Law, N.Y. Times, Apr. 25, 1998, at A2:

Dennis Karjala, a law professor at the University of Arizona, has noted that under the new law our rolypoly Santa Claus, originally created by the I9th century cartoonist Thomas Nast, would not have gone into the public domain until 1973. Even the United States Government 
viewed from a present-value perspective, the additional incentive to create a copyrightable work is negligible for an extension of copyright from lifeplus-fifty years to life-plus-seventy years. ${ }^{224}$ Thus, the major beneficiaries of such an Act are not future creators, but current copyright owners-and the larger the library of revenue-producing copyrights, the greater the future benefit. Consumers, on the other hand, pay the full costs of these benefits. But they pay them in small doses individually, and over a long period of time. Thus, the absence of effective lobbying against the Act. This leaves only two obstacles in the path of this type of legislation: Congressional rectitude and judicial review. Only the most cynical would argue that the former is meaningless; and only the most optimistic would argue that it will always prevail. ${ }^{25}$ Thus we will at times be left with the somewhat thin reed of judicial review.

But only at times. In many cases, proposed legislation in this area not only confers "clear and present" benefits; it imposes identifiable costs on well-organized interest groups as well. These groups rise up in opposition, producing the sort of "legislative balancing" described by pluralist interestgroup theorists. ${ }^{226} \mathrm{~A}$ recently-proposed database protection bill is a prime example. ${ }^{227}$ Partly as a result of a Supreme Court opinion limiting copyright protection in factual compilations, ${ }^{228}$ database owners have pushed legislation creating special protection for databases. But they have been opposed (successfully, so far) by other interest groups. In addition to the "usual suspects"-research libraries and consumer groups-the forces of opposition have included some large firms that rely on free access to information for their products and services. ${ }^{229}$ Bloomberg News Service is a

would have had to pay royalties to use Nast's Uncle Sam in all of this century's wars. Just as Uncle Sam and Santa eventually became part of the public domain, available for anyone to use in any season, so eventually should Mickey Mouse and Bugs Bunny take their places in our freetoall panthcon of cultural icons.

224. See generally, Robert Patrick Merges \& Glenn Harlan Reynolds, Essay, The Proper Scope of the Patent and Copyright Power, 37 HARv. J. ON LEgis. 45 (2000) (making the argument that this "plausible incentive" test ought to be incorporated into the jurisprudence of constitutional review of IP legislation).

225. Cf. Jonathan R. Macey, Promoting Public-Regarding Legislation through Statutory Interpretation: An Interest Group Model, 86 CoLuM. L. REv. 223, 247-50 (1986) (discussing ways in which the structure of the Constitution impedes rent-seeking by interest groups); Robert $\mathrm{D}$. Tollison, Public Choice and Legislation, 74 VA. L. REv. 339 (1988) (overview of the "economic theory of legislation").

226. For an excellent description of public choice theory versus the theory of interest-group pluralism, see William N. EsKRIDGE, JR., ET AL., LEGisLation aND STATUTORY INTERPRETATION 8197 (2000).

227. For background, see J.H. Reichman \& Pamela Samuelson, Intellectual Property Rights in Data?, 50 VAND. L. Rev. 51 (1997).

228. Feist Publications., Inc. v. Rural Tel. Serv. Co., 499 U.S. 340 (1991).

229. The implied skepticism of the phrase "the usual suspects" is not meant to disparage these lobbying groups. It indicates only that they are usually outgunned in legislative debates in terms of money and human resources. $C f$. SchLOZMAN \& TIERNEY, supra note 220 , at $74-87,111,128,387-89$ 
prominent example. Concerned that the new legislation will make it expensive or impossible to freely disseminate financial information such as stock and commodity prices, Bloomberg has hired lobbyists and actively opposed the legislation, so far with success. ${ }^{230}$

Nor is database protection an isolated instance. Industrial designers have long sought a new form of industrial design protection to replace the current ineffective system of design patents. They have been thwarted every time by the auto insurance industry, however, which is concerned lest legally protected auto body parts eliminate the insurers' practice of buying less-expensive replacement body parts from third parties. ${ }^{231}$

As these examples demonstrate, the specter of legislative imbalance is not always present. Yet this is in no way fatal to the point I am trying to make. I am arguing only that, when an imbalance is clear, courts ought to treat it as relevant. In a close case, where a statute seems close to a line drawn by the Constitution, it should be relevant that only industry groups were represented during the drafting of the statute. Not determinative; but relevant. ${ }^{232}$ A copyright term incapable of serving as an incentive at any plausible discount rate; a private patent bill tucked into an unrelated piece of legislation granting a long extension for no justifiable reason: in these

(statistics show that consumer groups accounted for only 10 percent of all interest groups in 1980); Shawn Zeller, Lobbying \& Law From The K Street Corridor, NAT'L J., Dec. 12, 1998:

With the battle over copyright legislation set to heat up again in January, Bloomberg, the electronic publisher of financial news, has jumped into the fray and hired two lobbying firms, Royer \& Babyak, and Parry and Romani Associates Inc. Bloomberg joins a long list of legal publishers, research libraries, and consumer groups who argue that proposed copyright legislation would give too much protection to databases, which in many instances are merely collections of facts. Bloomberg is particularly concerned that the legislation could hinder its ability to publish, on its 'Web site, financial information gathercd from other sourccs. "It could kill electronic commerce," the Bloomberg spokesman said. Bloomberg and its allies are squaring off against a number of information sellers, such as the Thomson Corp. Those Id. companies and their allies have formed the Coalition Against Database Piracy.

230. See Zeller, supra note 229 .

231. See William S. Thompson, U.S. Design Protection: Discussion Of Status And Suggested Proposals, 24 AIPLA Q.J. 393, 395-96 (1996):

[I]n the past ten to fifteen years, sui generis design protection has been vigorously and effectively opposed by a well financed lobby representing the auto insurance interests. Such lobbyists have not only defeated legislation in the United States, but created a virtual standstill to similar initiatives in the European Community. The motivation of the auto insurance lobby is straightforward: by requiring an insured client to use cheaper offshore crash parts, the companies cut costs on replacement parts used to repair vehicles. Setting aside such questions concerning quality of the parts used and who benefits from the cost reduction, effective'design protection is viewed as an impediment to this initiative. It is interesting to observe that there is nothing in the current design patent system which precludes granting protection to auto crash parts. Thus, this lobby obviously doesn't oppose design protection for crash parts-as long as it is the current ineffective design patent system.

232. Of course, even the most "imbalanced" procedure is capable of producing a perfectly legal statute; perhaps there was no opposition because the legislation was without doubt necessary. Or perhaps it is trivial. And at the same time, a perfectly "balanced" procedure-with an equal number of witnesses and lobbyists on every side of an issue-may nevertheless produce an unconstitutional statute. 
and similar cases, an inquiry into the legislative process seems a relevant consideration. ${ }^{233}$ In a close case, that inquiry should tip the balance. A court could then invalidate the statute, returning the issue to Congress. If a better case for the statute can be inade under the Intellectual Property Clause and/or the First Amendment (if relevant), Congress might pass it again. In a close case, the refornied process might justify a court in upholding the statute on second review.

In the end, it is less important whether this specific approach or another one is chosen. The point remains the same: in an age of increasing "statutorification" in intellectual property law, the systein needs a counterweight where the legislative process is skewed. The Intellectual Property Clause of the constitution, long dormant, seems the best candidate.

\section{B. The Second Deadly Sin: The Shifting Baseline}

In the end, intellectual property rights are delicate things. The intangible nature of the subject inatter ineans that the definition of each right, as well as the limits and exceptions, takes shape purely in the realm of the conceptual. There is no hard physical reality to which we can refer that will help define the boundaries of such a right. There are no natural facts to act as a brake on expansive notions of how broad a right might be, how many people and activities it might reach, or how long it might last. This is of more than passing interest. It means that what brakes and limits there are in this domain exist in our minds, or are encoded in the conceptual rules and principles that conprise this body of law. Any change in the fundamental underpinnings of the rules thus has potentially serious implications.

I believe we are in the midst of just such a change. ${ }^{234}$ The shift that has occurred has taken place at the deepest substratuin of the field, down where the foundational principles buinp and grind against each other. One massive construct, the principle of the competitive baseline, has started to give way. Under this notion, IP rights were envisioned as a rare exception. The general rule-the law's deep default-was open and free competition. This was always opposed by a counter-principal, the idea that labor equals property. On this view, property rights are a matter of desert: in true Lockean fashion, property arises when you mix your effort with the found assets of the natural world. When seen from the perspective of laboring creators, the proper baseline is to protect all inanifestations of creativity that take more than a trivial amount of effort. This was a powerful principle, to be sure, but until recently not usually powerful enough. The great tectonic shift of recent years has reversed this, however. Now it often

233. Unfortunately, courts do not necessarily agree. See Eldred v. Reno, 74 F. Supp. 2 d 1 (D.D.C. 1999) (upholding twenty-year copyright term extension against consitutional challenge).

234. For a contrary assessment, see Frank H. Easterbrook, Cyberspace Versus Property Law?, 4 Tex. Rev. L. \& PoL. 103 (1999) (all is well). 
seems as though the labor-equals-property principle dominates. Increasingly, courts and legislators seem to believe that if one type of labor deserves a property right, then others do as well. And so all manner of intangibles meet with protection-even when, in the past, the competitive baseline would have militated against it.

The long-term threat of this shift is obvious. It might result, to borrow a phrase, in "too much property." Unfortunately, after a court does extend a property right in a new direction, the legislative dynamic described in Part IV. A kicks in. This makes it difficult to turn back a judicially initiated extension of rights. There is a threat, then, that the process of judicial expansion, coupled with the new political economy of IP rights, may spell a deadly tandem from the public interest point of view.

\section{CONCLUSION AND PROSPECTS}

Looking back over the course of the century, one is impressed by two main themes. First, the advent of new technologies has left its mark on all areas of intellectual property law, not just patent law. I would not go so far as to say that intellectual property ought to be made a branch of the history of technology, but I would say that history is highly relevant to understanding the evolution and current state of this body of law.

The second theme is that the intellectual property lawmaking system has done a fairly admirable job adapting to the new technologies. The courts have sometimes led the way. Congress has also stepped in to remedy judicial omissions and to consolidate doctrinal developments in newly stated general rules. The IP system has no doubt made some mistakes, overprotecting some technology-or information-intensive assets, and underprotecting others. But, on the whole, the system has seldom appeared to truly disrupt viable economic activity, and has unquestionably furthered economic growth in various cases to varying degrees.

At a minimum, intellectual property has made a modest but important contribution to the economic well-being of our country this century. This may seem a diminutive claim to fame, especially in an essay commissioned to celebrate a big event, the turning over of the millennial odometer. But I think it is quite significant. Given the many inadequacies of the legal system as a whole, not to mention its outright failures, a body of law that can claim even some degree of effectiveness is no small matter. At any rate, IP law seems to have earned its keep this century, therefore perhaps justifying another hundred years of attention, concern, and maybe even solicitude. 